\title{
Role of IGF-binding proteins in regulating IGF responses to changes in metabolism
}

\author{
David R Clemmons \\ Department of Medicine, UNC School of Medicine, University of North Carolina, Chapel Hill, North Carolina, USA \\ Correspondence should be addressed to D R Clemmons: endo@med.unc.edu \\ This paper forms part of a special section on 40 years of IGF1. The guest editors for this section were Derek LeRoith and Emily Gallagher.
}

\begin{abstract}
The IGF-binding protein family contains six members that share significant structural homology. Their principal function is to regulate the actions of IGF1 and IGF2. These proteins are present in plasma and extracellular fluids and regulate access of both IGF1 and II to the type I IGF receptor. Additionally, they have functions that are independent of their ability to bind IGFs. Each protein is regulated independently of IGF1 and IGF2, and this provides an important mechanism by which other hormones and physiologic variables can regulate IGF actions indirectly. Several members of the family are sensitive to changes in intermediary metabolism. Specifically the presence of obesity/insulin resistance can significantly alter the expression of these proteins. Similarly changes in nutrition or catabolism can alter their synthesis and degradation. Multiple hormones such as glucocorticoids, androgens, estrogen and insulin regulate IGFBP synthesis and bioavailability. In addition to their ability to regulate IGF access to receptors these proteins can bind to distinct cell surface proteins or proteins in extracellular matrix and several cellular functions are influenced by these interactions. IGFBPs can be transported intracellularly and interact with nuclear proteins to alter cellular physiology. In pathophysiologic states, there is significant dysregulation between the changes in IGFBP synthesis and bioavailability and changes in IGF1 and IGF2. These discordant changes can lead to marked alterations in IGF action. Although binding protein physiology and pathophysiology are complex, experimental results have provided an important avenue for understanding how IGF actions are regulated in a variety of physiologic and pathophysiologic conditions.
\end{abstract}

\author{
Key Words \\ - bone \\ - cardiovascular \\ - diabetes (all) \\ - growth factor receptors \\ - growth factors
}

\section{Introduction}

The IGF-binding proteins are a family of six proteins that contain specific amino acids in their amino and carboxyl terminus that mediate high-affinity IGF binding (Clemmons 2016). These regions of sequence are highly conserved in all six members of the family; therefore, the mechanism by which this high-affinity interaction with the IGFs is mediated is common among the six members

\begin{tabular}{|lr}
\hline $\begin{array}{l}\text { http://jme.endocrinology-journals.org } \\
\text { https://doi.org/10.1530/JME-18-0016 }\end{array}$ & ○ 2018 Society for Endocrinology \\
Published by Bioscientifica Ltd. \\
Printed in Great Britain
\end{tabular}

of the family. Importantly for understanding their role in regulating IGF1's metabolic effects is the observation that these proteins do not bind insulin; therefore, they have no effect on insulin's interaction with its receptor. The affinity of all of the forms of IGFBPs is higher than the IGF1 receptor and when IGF1 or II is bound to an IGFBP, it does not activate the receptor. Therefore, a major
Journal of Molecular Endocrinology (2018) 61, T139-T169 
function of these proteins is to regulate IGF bioavailability. Cleavage of IGFBPs by specific proteases results in a major reduction in their affinities, and this is accompanied by an increase in free IGF. Several investigators have prepared protease-resistant mutant forms of IGFBPs and infused them into animals or added them to cultured cells and shown that they can inhibit IGF actions (Conover et al. 1995, Nichols et al. 2007). The identification of proteases, such as PAPP-A that cleave IGFBPs has made it possible to modulate IGFBP cleavage and thereby assess the role of IGFBP proteolysis in regulating IGF1's metabolic actions (Mikkelsen et al. 2014).

In addition to their ability to regulate ligand-receptor interactions, the members of this family also have IGF1ndependent effects. The preparation of mutant forms of each form of IGFBP that have reduced affinity but retain the ability to interact with other cellular proteins has allowed definitive testing of this hypothesis. However, the term IGF1ndependent effects can be interpreted in two ways. The most conservative interpretation is effects that are mediated without IGF binding to the IGFBP. These can clearly be tested with nonbinding mutants. However, a broader interpretation includes effects that are mediated through protein-protein interactions that are not completely IGF independent in the sense that may alter IGF signaling through the IGF receptor. Such an effect by definition would not be IGF independent. Therefore, using this definition to definitively prove that an IGF-binding protein effect is truly IGF independent requires the use of cells in which IGF synthesis has been inhibited or receptor activation has been attenuated following binding protein addition. Many of the published experiments have not utilized these controls; therefore, the conclusion that their effects are IGF independent often requires modification. Nevertheless, such experiments have led to an interesting line of research that is highly relevant to understanding the metabolic actions of IGFBPs. Some examples of these non-IGF-dependent effects include interaction with extracellular matrix proteins (Jones et al. 1993b), cell surface proteoglycans (Russo et al. 1997) or with specific cell surface receptors (Andress 1998) (Fig. 1). Additionally interactions with a variety of intracellular targets including PPAR gamma, RXR receptors, LIM protein family members, GRP 78, endoplasmic reticulum chaperone proteins, specific proteins in the nuclear membrane that mediate nuclear translocation and specific transcription factors have been identified (Martin \& Baxter 2011). In some cases, the mechanism by which these protein-protein interactions modify IGF signaling through its receptor has been determined. These protein-IGFBP interactions are

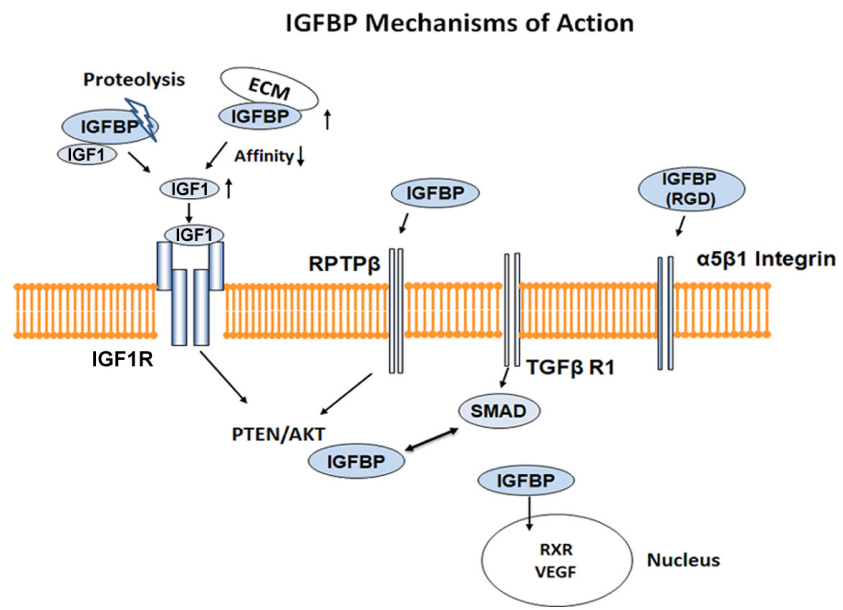

Figure 1

IGFBPs have the capacity to function by one of multiple mechanisms some of which involve binding IGFs and some by interacting with other receptors or signaling systems.

often mediated through the linker region or C-terminal domain of IGFBPs. Unlike the carboxyl or amino terminus, the linker region has no sequence conservation among the six members of the family; therefore, protein-protein interactions that are mediated through this region can be specific for a single form of IGFBP. An example would be the heparin-binding domain sequence contained in IGFBP2, which interacts with proteoglycans (Russo et al. 1997). This sequence is only present in IGFBP2. Therefore, the metabolic consequences of this interaction are unique to this IGFBP. The C-terminal domain is the most highly conserved region; thus, the interactions mediated through this region may not be specific and may apply to multiple IGFBPs.

An additional concept that is important for understanding the ability of the IGFBPs to regulate metabolism is the distinction between locally secreted BPs (autocrine/paracrine effects) and IGFBP actions that are mediated via transport through the circulation (endocrine effects). The liver is the primary source of blood-borne IGFBPs and therefore identification of the factors that regulate hepatic synthesis has contributed to our understanding of their endocrine actions. In general, IGFBP3 and 5 account for much of the bound IGF in serum for two reasons; (1) they have very high affinity for IGF1 and II; (2) they bind to a third protein acidlabile subunit (ALS), which prolongs their half-lives and therefore extends IGF half-life much better than the other members of the family (Jones et al. 1993a). Therefore, in terms of understanding IGF transport to tissues, these two family members are extremely important. In contrast, since many of the metabolic actions of IGF1 and II are 
mediated by the free peptide the importance of IGFBP1, 2, 4 and 6 is their ability to regulate free peptide availability. Analysis of binding capacity of serum shows that while IGFBP3 and 5 are saturated under normal physiologic conditions, IGFBP1 and 2 are unsaturated (Baxter 1994). Therefore, following acute changes in an IGFBP such as suppression of IGFBP1 after a high carbohydrate meal, there are major changes in free IGF1 (McCusker et al. 1989). Understanding how these acute changes in free IGF1 in blood translate into changes in free IGF1 in interstitial fluids and in receptor bioavailability is not well defined at present. This is an important area for future studies.

In contrast to endocrine actions, autocrine/paracrine effects are dependent primarily upon cell type-specific changes in the synthesis and secretion of specific forms of IGFBPs. For example, normal skin fibroblasts secrete primarily IGFBP3, 4 and 5, whereas vascular smooth muscle cells (VSMC) secrete primarily IGFBP2 and 4. Since these IGFBPs may have unique actions, this implies that this is one mechanism for mediating cell type specific changes. Several IGFBP actions that regulate metabolism are cell type specific; therefore, the metabolic factors that regulate IGFBP synthesis and/or degradation as well as posttranslational modifications that regulate their affinities can alter cellular metabolic responses.

There is minimal data regarding specific cell surface receptors that are linked to intracellular signaling mechanisms that bind to IGFBPs. Exposure of fibroblasts to the IGFBP3 was shown to trigger a phosphatase that altered IGF1 signaling, however, a specific receptor that mediated this interaction was not identified (Lewitt \& Baxter 1991). Subsequent studies indicated that IGFBP3 could bind to the type V TGF- $\beta$ receptor. This was later determined to be LRP-1 (Ricort \& Binoux 2002). This resulted in LRP-1 phosphorylation and was associated with changes in cell behavior. However, the signaling elements that were activated were not determined. IGFBP3 has been shown to alter signaling through the TGF$\beta 1$ and 2 receptors and deletion of the TGF- $\beta 2$ receptor inhibits the ability of IGFBP3 to activate SMAD proteins, a component of the TGF- $\beta$ signaling pathway (Leal et al. 1999). This results in sphingosine kinase stimulation and transactivation of the epidermal growth factor receptor (Fanayan et al. 2002). IGFBP1 interacts directly with the $\alpha 5 \beta 1$ integrin through its RGD-binding sequence (Fig. 1). This results in alterations in IGF action and direct stimulation of cell migration (Martin et al. 2014).

Recently, a tightly linked signaling mechanism coupled to a specific receptor for IGFBP2 has been identified. IGFBP2 contains a unique heparin-binding domain in its linker region that is not contained in any of the other forms of IGFBPs. Specific amino acids in this region interact with a cell surface receptor termed receptor protein tyrosine phosphatase beta (RPTP $\beta$ ). Binding to RPTP $\beta$ leads to inhibition of its polymerization and inhibition of its tyrosine phosphatase activity (Shen et al. 2012). A major target of RPTP $\beta$ is PTEN an inhibitor of AKT activation. Following IGFBP2 engagement, there is enhanced PTEN tyrosine phosphorylation, which inhibits degradation of inositol 3 phosphate resulting in enhanced AKT activation. This signaling mechanism alters several IGFBP2 dependent metabolic functions.

Although the mechanism by which IGFBPs regulate the growth response to IGF1 and IGF II is beyond the scope of this review, it is important to point out that growth and metabolism are inextricably intertwined, therefore, understanding how the IGFBPs regulate metabolic responses is critical for interpreting their actions on somatic growth. The IGFs act as intermediaries between nutrient availability and growth regulation. Therefore, the actions of the IGFBPs in modulating these responses have both direct and indirect effects on cellular responses to changes in energy source availability. Many of the same nutritional variables that regulate IGF1 and II also coordinately regulate the IGFBPs. In contrast, in states of severe metabolic derangement, such as diabetes, regulation may become discordant, and this may result in pathophysiologic responses. The availability of transgenic and knockout animals has greatly contributed to our understanding of how these complex interactions influence organismal growth and metabolism.

\section{Role of IGFBPs in regulating fat metabolism}

Many of the publications regarding the effects of IGFBPs on fat metabolism have been derived from human or whole animal studies in which the serum concentration of the IGFBP is correlated with changes in fat mass or fat metabolism. Studies that have analyzed direct effects of IGFBPs on isolated adipocytes or fat tissue in animals are much less prevalent but some information is available regarding their direct actions.

\section{IGFBP1}

Direct addition of IGFBP1 to pre-adipocyte cultures inhibits proliferation and differentiation and IGFBP1 transgenic mice show reduced fat mass (Rajkumar et al. 1999, Siddals et al. 2002). Studies utilizing cells derived 
from these animals have shown that IGFBP1 inhibits IGF1 stimulation of pre-adipocyte differentiation. When IGFBP1 transgenic mice were fed a high calorie diet, they gained significantly less fat mass compared to control mice (Rajkumar et al. 1999). IGF1 stimulates pre-adipocyte differentiation, thus, it was proposed that IGFBP1 functions by inhibiting IGF1's actions. The phosphorylated form of IGFBP1 was fivefold more effective than the nonphosphorylated form. The molecular explanation for this observation is that phosphorylation of IGFBP1 enhances its affinity for IGF1 sixfold (Jones et al. 1991). Since insulin inhibits IGFBP1 synthesis, the results support the conclusion that hyperinsulinemia that occurs in states of obesity and insulin resistance suppresses IGFBP1 leading to enhanced adipogenesis. Conversely, weight loss and restoration of more normal physiologic insulin secretion leads to an increase in IGFBP1, which inhibits adipogenesis (Wheatcroft \& Kearney 2009). A specific receptor that is mediating these effects has not been identified, and they are presumed to be mediated only by changes in IGF1 receptor activation.

The initial studies of IGFBP1 in humans showed that it was markedly suppressed by insulin and that following ingestion of a mixed meal or carbohydrate, there was major suppression in serum IGFBP1 (Busby et al. 1988, Lewitt et al. 2010). Not surprisingly, follow-up studies showed that obese subjects particularly those who were hyperinsulinemic had a low IGFBP1 (Lewitt et al. 2010). Since IGFBP1 is produced almost solely in the liver, these changes are result of suppression of hepatic synthesis; therefore, any effect of IGFBP1 on fat mass accumulation would be mediated by changes in endocrine transport. Both obese and non-obese subjects are highly insulin responsive in terms of insulin-induced IGFBP1 suppression. Both acute and chronic caloric restriction results in highly significant increases in IGFBP1, and these changes correlate with fat mass loss (Reinehr et al. 2011, Henning et al. 2013). Similarly, refeeding an isocaloric diet after prolonged energy restriction results in a major decrease. The extent of IGFBP1 suppression in obesity can be profound since women who were greater than $107 \mathrm{~kg}$ over ideal body weight had undetectable IGFBP1 levels (Weaver et al. 1990). Overfeeding results in a substantial reduction in IGFBP1 that correlates with changes in increases in abdominal visceral fat (Ukkola et al. 2001). Longitudinal studies show that changes in IGFBP1 predict the development of metabolic syndrome. Specifically, children followed over time who developed metabolic syndrome had significantly lower IGFBP1 levels compared obese children who did not develop metabolic syndrome (Reinehr et al. 2011). IGFBP1 correlates with several variables of metabolic syndrome including HDL cholesterol, triglycerides, proinsulin and measures of insulin sensitivity as well as PAI-1 (Mohamed-Ali et al. 1999). A study of adults who had been born for a small for gestational age showed that IGFBP1 was inversely related the body mass index, fasting glucose and insulin (van der Kaay et al. 2009). IGFBP1 predicted the fasting insulin and the insulin area under the glucose tolerance test curve in obese adolescents and phosphorylated IGFBP1 predicted the degree of liver fat content (Petäjä et al. 2016). There is also a longitudinal association between the degree of suppression of IGFBP1, and the development of markers of the metabolic syndrome in obese children before and after weight loss (Reinehr et al. 2011). Similarly, the change in IGFBP1 after glucose ingestion is an excellent predictor of hepatic insulin resistance (Kotronen et al. 2008). These data support the conclusion that there is a strong relationship among IGFBP1, fat mass and insulin sensitivity.

\section{IGFBP2}

Differentiating pre-adipocytes secrete predominantly IGFBP2 (Boney et al. 1994) and direct addition of IGFBP2 inhibits adipogenesis in 3T3-L1 cells (Wheatcroft et al. 2007). In vitro studies have shown that two regions of sequence within IGFBP2 termed heparin-binding domain-1 and heparin-binding domain-2 are the most important for inhibiting adipogenesis (Fig. 2). Specifically, addition of peptides containing those sequences was as effective as the native protein in inhibiting the response of pre-adipocytes to insulin-stimulated differentiation (Xi et al. 2013). That this effect was independent IGF binding to IGFBP2 was demonstrated by showing that IGFBP2 inhibited the effect of insulin, which does not bind IGFBPs and that these peptides that contain no IGF-binding activity were equipotent with native IGFBP2. Addition of IGFBP2 to human visceral pre-adipocyte cultures showed reduced fat cell differentiation and silencing IGFBP2 in visceral adipocytes was associated with enhanced

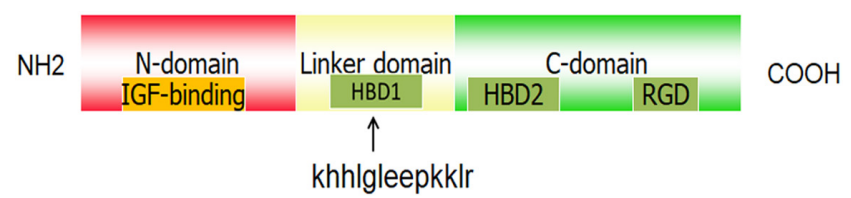

Figure 2

Schematic diagram of domains in IGFBP2 mutagenesis studies have shown that each of these domains has a distinct function. 
adipogenesis but had it no effect and subcutaneous adipocytes (Russo et al. 2015). This is consistent with the transgenic overexpression data, which show a preferential effect on visceral fat. Wheatcraft et al. showed that transgenic mice overexpressing IGFBP2 were resistant to diet-induced fat accumulation and had enhanced insulin sensitivity compared to controls (Wheatcroft et al. 2007). The difference between visceral and subcutaneous adipose tissue was further amplified by Li and Picard who demonstrated that constitutive expression of IGFBP2 is preferentially decreased in obese mice in visceral fat (Li \& Picard 2010). Overexpression of a form of IGFBP2 in which this HBD-1 sequence was altered showed that the mutant had no effect on fat mass, and these mice preferentially gained fat (Wiedmer et al. 2015). Studies in rodents show that leptin stimulates IGFBP2 expression in the liver and that these changes correlate with changes in body weight and glucose metabolism (Hedbacker et al. 2010).

Results from studies of IGFBP2-knockout mice also support the conclusion that IGFBP2 inhibits adipogenesis. Specifically, male IGFBP2 -/- mice become obese (30\% over ideal body weight) by age 3 months and their weight remains significantly greater than controls for one year (DeMambro et al. 2008). These changes occur on a normal diet suggesting that physiologic levels of IGFBP2 regulate fat mass. Administration of a peptide containing the HBD-1 domain resulted in significant attenuation of weight gain and inhibited gain of fat mass (Kawai et al. 2011). Taken together, the results strongly support the conclusion that IGFBP2 has direct effects on fat metabolism and that these effects are preferential for visceral fat. However, the receptor that is mediating these effects has not been definitively determined.

Human studies measuring IGFBP2 have focused primarily on obesity and metabolic syndrome. When obese, prepubertal children were compared to normal weight subjects IGFBP2 concentrations were significantly lower (Radetti et al. 1998). Since IGFBP2 is much less sensitive to suppression by insulin, it is possible that other hormonal variables are also suppressing IGFBP2. Cytokines that are increased in obesity, such as, IL-6 and TNFa inhibit IGFBP2 (Street et al. 2013). Another proposed mechanism that contributes to IGFBP2 suppression is hypermethylation of the gene, which occurs in response to high-fat feeding in mice (Kammel et al. 2016). In subjects who are overweight (BMI 28.9) IGFBP2 correlates independently with insulin sensitivity and IGF bioactivity suggesting that loss of suppression of IGF bioactivity in obesity may contribute to changes in insulin sensitivity (Nam et al. 1997, Arafat et al. 2009, Claudio et al. 2010).
As for IGFBP1 reversibility of the obese state is associated with upregulation of IGFBP2. Obese patients undergoing bilopancreatic diversion showed a substantial increase in IGFBP2 in association with weight loss and improvement in metabolic syndrome parameters such as triglycerides and HDL cholesterol (Li et al. 2012). A longitudinal study showed that IGFBP2 predicted long-term changes in HDL cholesterol that occurred in association with the development of metabolic syndrome (Narayanan et al. 2014). Similarly IGFBP2 levels in adults correlate with the development of increasing VLDL triglycerides (Carter et al. 2014). Nam et al. reported that IGFBP2 concentrations were inversely related to free IGF1 in obese subjects suggesting that these effects are mediated through loss of suppression of IGF1-stimulated pre-adipocyte differentiation (Nam et al. 1997). Prepubertal and pubertal subjects who were born small for gestational age (SGA) had lower IGFBP2 levels compared to non-SGA children and later in life, IGFBP2 levels in post-SGA children continue to correlate with BMI, fat mass, triglycerides and insulin levels (de Kort et al. 2010). Therefore, like IGFBP1, IGFBP2 correlates with changes in fat mass, insulin sensitivity and metabolic syndrome, but the mechanisms that regulate these changes are more diverse.

\section{IGFBP3}

IGFBP3 interacts with the PPAR $\gamma$ receptor and inhibits its dimerization with RXR thereby blocking ligand-induced transactivation of PPAR $\gamma$ in pre-adipocytes (Chan et al. 2012). Additional studies showed that IGFBP3 activated Smad signaling in pre-adipocytes (de Silva et al. 2009). This signaling system is known to mediate the anti-lipogenic effect of TGF- $\beta$. IGFBP3 stimulates SMAD phosphorylation and knockdown of IGFBP3 in vitro impaired SMAD activation in response to TGF- $\beta$ suggesting that TGF$\beta$ was working through IGFBP3 (de Silva et al. 2009). In vivo studies have been less definitive. Although transgenic mice overexpressing IGFBP3 had some reduction in body weight, analysis of the fat compartment was not reported (Yakar et al. 2009). One study demonstrated that overexpression of wild-type IGFBP3 had no effect on fat mass compared to control mice, but overexpression of a non-IGF-binding mutant of IGFBP3 was associated with increased fat mass (Nguyen et al. 2015b). This suggests that under physiologic conditions, IGFBP3 may be acting to attenuate the effect of IGF1 in stimulating pre-adipocyte differentiation. It is also possible that IGFBP3 was inhibiting fat accumulation by a mechanism independent of IGF binding. Interestingly, this group 
reported that IGFBP3 and the non-IGF-binding mutant stimulated brown adipocyte differentiation (Nguyen et al. 2015a).

Population-based studies of IGFBP3 show that it correlates positively with total or LDL cholesterol, triglycerides and inversely with HDL cholesterol (Eggert et al. 2014). Similarly, the IGF1/IGFBP3 ratio correlates with the development of metabolic syndrome and insulin resistance (Eggert et al. 2014). Analysis of older men showed that IGF1/IGFBP3 had a U-shaped relationship with the odds of development metabolic syndrome (Savastano et al. 2011). Subjects in the lowest quartile and the highest quartile of IGFBP3 had the greatest probability. Notably IGFBP3 was positively associated with all five components metabolic syndrome. A strong positive correlation between IGF1, IGFBP3 and HDLC has been confirmed in elderly adults (Yeap et al. 2010). Analysis of 1291 subjects with cardiovascular risk factors showed that IGFBP3 correlated with triglycerides and total cholesterol. Follow-up over 10 years showed that increasing IGFBP3 was associated with increased cholesterol (Ceda et al. 1998).

\section{IGFBP4}

IGFBP4 is secreted by human pre-adipocytes prior to differentiation and its secretion does not appear to increase during differentiation in vitro (Boney et al. 1994). An important property of IGFBP4 is its ability to inhibit IGF1-stimulated angiogenesis (Contois et al. 2012). Angiogenesis is an important component of fat depot formation, and IGF1 stimulates endothelial cell sprouting in vitro. Addition of IGFBP4 blocked the effects of either insulin or IGF1 on adipose tissue sprouting (Gealekman et al. 2014). Furthermore, IGFBP4 levels were shown to decrease with aging in animals and with high-fat diet-induced adipose tissue expansion. Since IGFBP4 can block insulin-induced sprouting, this suggests that it is suppressing adipogenesis though its effects on angiogenesis and that its effect is not mediated through binding IGF1. A cell surface receptor that might mediate this effect has not been identified.

In summary, IGFBPs 1-4 modulate pre-adipocyte differentiation in vitro. Definitive studies in genetically manipulated animals are only present for IGFBP1 and 2 and suggest that these proteins, particularly IGF BP-2, function to directly inhibit pre-adipocyte expansion. This limitation of definitive understanding of molecular mechanisms by which the IGFBPs may alter pre-adipocyte differentiation has limited the amount of information that can be drawn from human studies since these generally involve measuring changes that occur in serum IGFBPs after a particular metabolic manipulation. Human study data interpretation is also limited by the fact that very few studies have analyzed adipose tissue obtained from the subjects. Wherein this has been performed, the data have provided new and useful information.

The findings clearly support the conclusion that IGFBP1 and 2 function by regulating free IGF1 concentrations and thereby inhibiting the ability of IGF1 to stimulate pre-adipocyte differentiation. Additionally, both peptides have IGF1ndependent effects that regulate fat mass accumulation and possibly insulin sensitivity. However the receptors and signaling mechanisms that mediate these effects have not been delineated. In contrast, IGFBP3 while capable of lowering free IGF1, is generally saturated therefore it appears to function predominantly by providing a consistent reservoir of IGF1 to stimulate pre-adipocyte differentiation and its net effects are the opposite of IGFBP1 and 2. This conclusion is consistent with the known mechanisms that regulate the synthesis and secretion of these forms of IGFBPs. The major challenge for the future is to dissect out those effects that are purely associative versus those wherein the specific form of IGFBP is the primary causal driver of the change in fat mass and/or insulin sensitivity.

\section{Carbohydrate metabolism and diabetes}

\section{IGFBP1}

IGFBP1 is regulated acutely by changes in carbohydrate metabolism. The primary source of IGFBP1 is hepatic synthesis. The IGFBP1 gene contains an insulinsensitive response element that directly suppresses its transcription in response to increased hepatic insulin exposure (Suwanickul et al. 1993). As would be predicted following ingestion of a normal carbohydrate meal, there is suppression of IGFBP1, and following fasting, there is a 3- to 4-fold increase in IGFBP1 serum concentrations (Lewitt \& Baxter 1991, Contois et al. 2012). Therefore, IGFBP 1 levels fluctuate throughout the day depending on food intake and fasting intervals. Glucocorticoids and hepatic nuclear factor-1 stimulate IGFBP1 synthesis (Bae et al. 2013). In states of significant insulin resistance such as type II diabetes, there is differential sensitivity to insulin actions, therefore, although glucose transport in skeletal muscle is markedly inhibited, the ability of insulin to suppress IGFBP1 synthesis in the liver is retained. Chronic caloric restriction also results in 
sustained IGFBP1 increases and modest caloric restriction for period of two years resulted in the sustained 21\% increase in IGFBP1 (Fontana et al. 2016). The suppression of IGFBP1 that occurs postprandially is not entirely due to insulin suppression of hepatic synthesis. Specifically ingestion of fructose, which induces minimal changes in insulin secretion results in a 35\% reduction in IGFBP1 suggesting that stimulation of glycolysis also results in suppression of hepatic synthesis (Snyder \& Clemmons 1990). This reduction in serum IGFBP1 in response to carbohydrate ingestion results in an increase in free IGF1 thereby enabling it to enhance insulin-stimulated glucose transport. The converse is also true since infusion of a high concentration of IGFBP1 into normal rats resulted in a modest rise in plasma glucose (Lewitt \& Baxter 1991). In addition to regulating IGFBP1 concentrations, glucose and insulin regulate IGFBP1 phosphorylation (Nedić et al. 2011). Since phosphorylation increases the affinity of IGFBP1 for IGF1, this biochemical change regulates free IGF1 concentrations. IGFBP1 is phosphorylated by casein kinase-II, which is responsive to dietary manipulations such as leucine deprivation (Seferovic et al. 2009). Overexpression of IGFBP1 in transgenic mice was shown to attenuate the glucose-lowering effects of IGF1 and insulin. This was shown to be mediated in both skeletal muscle and adipose tissue (Crossey et al. 2000). The mice compensated by becoming hyperinsulinemic but elderly animals that could not mount an insulin response and had increased basal and postprandial glucose concentrations. This change was dependent upon IGFBP1 phosphorylation since transgenic overexpression of human IGFBP1, which could not be phosphorylated in mice did not result in changes in insulin or glucose (Sakai et al. 2001). Therefore, several studies support the conclusion that phosphorylated IGFBP1 regulates insulin responsiveness.

In type I diabetes, the absence of insulin results in marked increases in IGFBP1. Untreated type I diabetics had a 7-fold elevation, which decreased rapidly after insulin therapy (Bereket et al. 1995b). Not surprisingly, IGFBP1 levels fluctuate significantly in the subjects as a function of insulin dosage and insulin resistance. A study in Danish children showed that children at high risk of developing type I diabetes had higher IGFBP1 concentrations compared to controls and decreased residual beta cell function was associated with the degree of increase in IGFBP1 (Sorensen et al. 2015). A subset of type I patients with decreased methylation of the IGFBP1 gene had a greater increase in IGFBP1 (Gu et al. 2014).
IGFBP1 expression has been studied extensively in patients with type II diabetes. In older adults with modest glucose intolerance and relatively low IGFBP1 those who developed diabetes over a nine-year interval had a $57 \%$ increase in IGFBP1 at baseline as compared to a $25 \%$ increase in those who did not develop diabetes (Aneke-Nash et al. 2015). Because it is synthesized in the liver, IGFBP1 has been proposed as a specific marker of hepatic insulin sensitivity. Fasting IGFBP1 concentrations are inversely related to the liver fat content. Circulating IGFBP1 also correlates with hepatic insulin sensitivity (Kotronen et al. 2008). Obese subjects with impaired insulin sensitivity have significant reductions in IGFBP1 when compared to lean subjects. In contrast subjects with type II diabetes and similar degrees of insulin resistance had normal IGFBP1 concentrations (Gokulakrishnan et al. 2012). Based on those studies several investigators have examined whether IGFBP1 levels can predict the development of type II diabetes. Lewit et al. reported that middle-age men with IGFBP1 in the lowest quartile as compared to those in the highest quartile had a 40 -fold greater risk of developing type II diabetes after 10 years (Lewitt et al. 2008). A follow-up study in 664 nondiabetic subjects showed those in the lowest quartile at baseline had a $12.6 \%$ chance of developing type II diabetes in 7 years, whereas for those in the highest quartile it was 1.5\% (Petersson et al. 2009). Therefore, the hazard ratio was 3.54. An additional study analyzed the relationship between fasting IGFBP1 and waist circumference in predicting the development of type II diabetes. Following an eight-year interval, subjects in the highest quartile for waist circumference and the lowest tertile for IGFBP1 all developed type II diabetes (Lewitt et al. 2010). These findings have been independently confirmed. Strickler et al. demonstrated that follow-up data from the nurses' health study showed fasting IGFBP1 levels predicted the risk with an odds ratio of 2.05/1, and this correlated with the ability of free IGF1 levels to predict diabetes development (Rajpathak et al. 2012). Recently, it was noted that obese pregnant women with low IGFBP1 levels at 24-28 weeks were more likely to develop gestational diabetes (Ramirez et al. 2014).

Part of the mechanism of suppression of IGFBP1 in obesity and insulin-resistant states may relate to gene methylation. IGFBP1 DNA methylation levels were higher in newly diagnosed type II diabetics compared to control subjects with normal glucose tolerance and methylation was shown to reduce IGFBP1 secretion (Gu et al. 2013). Whether IGFBP1 plays a causal role in type 2 diabetes development has not been determined. One study 
showed that pioglitazone improves insulin sensitivity by inhibiting IGFBP1 synthesis thereby increasing free IGF1 and the change in IGFBP1 in subjects with established type II diabetes begun on pioglitazone correlates with a change in adiponectin (Arnetz et al. 2014). IGFBP1 was shown to increase beta cell regeneration by promoting alpha to beta cell transdifferentiation in mouse and human islets ( $\mathrm{Lu}$ et al. 2016). The authors speculated that this contributed to the propensity of low IGFBP1 to predict the development of type II diabetes over time.

In summary, these findings suggest that suppression of IGFBP1 in response to obesity reduces insulin sensitivity leading to chronic impairment of glucose tolerance and possibly contributing to the development of type II diabetes.

\section{IGFBP2}

In contrast to IGFBP1, IGFBP2 is much less acutely responsivetochangesinglucoseandinsulinconcentrations. Specifically, following insulin infusion into rats, IGFBP2 levels decreased slowly compared to IGFBP1 and fasting results in a slow incremental increase in IGFBP2 that occurs over 36-48 $\mathrm{h}$ as compared to the acute change in IGFBP1 (Clemmons et al. 1991, Ooi et al. 1993). Although insulin can suppress IGFBP2 transcription, it is much less effective compared to IGFBP1. Thus, IGFBP2 levels appear to correlate well with fat mass and insulin sensitivity over prolonged periods but are not altered by acute fluctuations in insulin secretion that occur postprandially. Following nine days of fasting, the substantial decrease in insulin concentrations was associated with only a 1.7fold increase in plasma IGFBP2 (Ooi et al. 1993). IGFBP2 levels are also very high in patients with anorexia nervosa (Argente et al. 1997). Extreme exercise has been shown to increase IGFBP2 (Berg et al. 2008). Nevertheless, IGFBP2 does play a role in postprandial glucose clearance since transgenic mice overexpressing a form of IGFBP2 in which the RGD sequence was mutated showed reduced glucose clearance as compared animals overexpressing wild-type IGFBP2, and this was associated with reduced levels of glucose transporters in the plasma membrane of muscle (Reyer et al. 2015). Prolonged fasting activates PPAR alpha, which binds to a PPAR-responsive element in the IGFBP2 promoter and upregulates IGFBP2 transcription (Kang et al. 2015). Additionally Kang et al. showed that metformin stimulates IGFBP2 expression through increases in PPAR alpha, and this response required activation of AMP kinase (Kang et al. 2016). As noted previously administration of leptin to insulin-resistant, leptin-deficient mice resulted in stimulation of IGFBP2, and hyperinsulinemic clamp studies in these animals showed that IGFBP2 administration improved hepatic insulin sensitivity (Hedbacker et al. 2010).

During clamp studies in humans, high-dose insulin infusion decreased IGFBP1, but it increased IGFBP2 resulting in a decrease in IGF bioactivity. Basal IGFBP2 correlated with insulin sensitivity and was lower in those with impaired glucose tolerance (Arafat et al. 2009). A study of 294 subjects showed that a longitudinal increase in IGFBP2 was associated with an increase in HDL cholesterol in patients with established type II diabetes (Narayanan et al. 2014). Following initiation of very low calorie diets in women with type II diabetes and obesity, there was an increased expression of IGFBP2 in fat accompanied by an increase in plasma IGFBP2 concentrations (Touskova et al. 2012). IGFBP2 has also been compared to IGFBP1 for its ability to predict the development of type II diabetes. The risk of developing diabetes was increased 5 -fold when IGFBP2 levels in the lowest quintile versus the top quintile in the nurse's health study as compared to a 2:1 risk ratio for IGFBP1 suggesting that it was a better predictor (Ramirez et al. 2014). When patients with untreated type I diabetes were compared to lean BMI-matched controls, there was no acute decrease in IGFBP2 levels during insulin therapy. In contrast, patients with reduced serum bicarbonate at presentation had a twofold elevation in IGFBP2, which returned to normal with insulin therapy (Bereket et al. 1995a).

In summary, high concentrations of IGFBP2 predict resistance to the development of diabetes. This has been shown in both obese, insulin-resistant, nondiabetic subjects followed prospectively over time as well as subjects with gestational diabetes. However, the molecular mechanism by which low levels of IGFBP2 predispose to diabetes has not been discerned. Furthermore, whether IGFBP2 has any direct effects on insulin-stimulated glucose transport is unknown. Although there is an associative relationship between changes in insulin sensitivity and changes in IGFBP2 whether IGFBP2 is directly affecting any of these properties or whether its ability to alter free IGF1 concentrations is contributing to changes in insulin sensitivity has not been determined.

\section{IGFBP3}

Similar to IGFBP2, there are minimal data regarding direct effects of IGFBP3 on glucose uptake or hepatic glucose output. IGFBP3 was shown to directly inhibit cytokineinduced insulin resistance in human aortic endothelial 
cells (Mohanraj et al. 2013) but IGFBP3 knockout mice showed normal plasma insulin and glucose values (Ning et al. 2006, Yakar et al. 2009). Nevertheless, after highfat feeding they developed fasting hyperinsulinemia and hyperglycemia but post prandial glucose tolerance was normal as was the response to a hyperinsulinemic clamp (Yamada et al. 2010). Clamp studies showed this change was not due to a change in insulin sensitivity but rather increased hepatic glucose output. In contrast, the IGFBP3, 4, 5 combined knockout animals had lower fasting glucose and enhanced insulin sensitivity (Ning et al. 2006). This change was replicated in ALS-knockout mice suggesting that the ternary complex of IGF, IGFBP3/5 and ALS is related to insulin sensitivity (Yakar et al. 2009). Transgenic mice overexpressing IGFBP3 developed glucose intolerance, and this effect was IGF1 independent (Silha et al. 2002). Mice showing the greatest increase in IGFBP3 developed fasting hyperglycemia and hyperinsulinemia. Aging male transgenic IGFBP3 mice show no change in fat mass but developed worsening glucose tolerance compared to controls (Nguyen et al. 2015b).

Several investigators have examined whether IGFBP3 levels like IGFBP1 and 2 would be useful in predicting the development of type II diabetes. Rajpathak et al. noted that IGFBP3 was positively associated with a trend to develop diabetes with an odds ratio of 2.0 and that the same group of subjects showed a relationship between free IGF1 values and diabetes development after 9 years (Ramirez et al. 2014). Other investigators have focused on the ratio between IGF1 and IGFBP3. Drogan et al. demonstrated that IGFBP3 was positively associated with development of type II diabetes but the ratio of IGF1/IGFBP3 was a stronger predictor of a trend (Drogan et al. 2016). The IGF1/IGFBP3 ratio also correlates with gestational diabetes development risk (Zhu et al. 2016). Aneke-nash et al. noted that older individuals with diabetes had a greater reduction in IGFBP3 over nine years as compared to nondiabetic controls (Aneke-Nash et al. 2017). Patients with severe type I diabetes and insulin deficiency have increased IGFBP3 proteolysis resulting in marked decreases in intact plasma IGFBP3 (Zachrisson et al. 2000). Two studies in type 1 diabetics have demonstrated a correlation between hemoglobin A-1C and IGFBP3 suggesting that it is related to glucose regulation (Kim \& Lee 2015). Patients with severe type I diabetes who have insulin administered via intraperitoneal infusion show substantial increases in IGF1 and IGFBP3 that are greater than subjects receiving a subcutaneous infusion suggesting that portal delivery of insulin inhibits proteolysis (van Dijk et al. 2016). Palau et al. postulated that fat around the pancreas secretes
IGFBP3 to regulate beta cell proliferation. Specifically the adipose depot secreted IGFBP3 and blocking secretion or activation of the IGF1 receptor inhibited beta cell proliferation (Palau et al. 2012). Coverley et al. showed that casein kinase-II phosphorylates IGFBP3, and this induces resistance to proteolytic cleavage (Coverley et al. 2000). Whether this increased stability of phosphorylated IGFBP3 could preserve some beta cell function and residual insulin secretion in patients with type I diabetes has not been analyzed. Administration of IGFBP3 with IGF1 to patients with either type I or type II diabetes has been shown to improve insulin sensitivity and glucose regulation (Clemmons et al. 2000, 2005, Saukkonen et al. 2006). Whether this is mediated through direct effects of IGFBP3 on beta cell function or indirect effects on insulin sensitivity has not been determined.

In summary, IGFBP3 being the major carrier of IGF1 tends to reflect changes that occur in IGF1. In type I diabetes, the extent to which this alters IGF1 action has not been definitively determined. High concentrations of IGFBP3 apparently alter hepatic glucose output but the mechanism by which this occurs is undefined. IGFBP3 concentrations in obese insulin-resistant subjects have some value for predicting the subsequent development of type II diabetes but are less robust markers than IGFBP1 and 2.

\section{IGFBP4}

Unlike IGFBP1-3, IGFBP4 has been analyzed primarily at the tissue level in experimental animals with diabetes. Analysis in diabetic rats showed that IGFBP4 mRNA was significantly decreased in skeletal muscle and liver after the induction of diabetes (Chen \& Arnqvist 1994). IGFBP4knockout mice did not have altered glucose metabolism; however, the triple knockout of IGFBP3,4,5 showed significantly increased insulin secretion after glucose challenge but the extent to which this was due to IGFBP4 was not determined. IGFBP4 expression is increased in the presence of hyperglycemia in skeletal myoblasts in culture, and this inhibits myoblast differentiation in response to IGF1 (Grzelkowska-Kowalczyk et al. 2013). Han et al. studied IGFBP4 serum concentrations in diabetic rats and found minimal change (Han et al. 2006). Humans with type I and type II diabetes and showed no difference in serum IGFBP4 when compared to control subjects; however, patients with macroalbuminuria had higher IGFBP4 levels compared to those who did not have this complication (Jehle et al. 1998). 


\section{IGFBP5}

IGFBP5-knockout animals did show mildly impaired glucose tolerance but no change in insulin resistance. Deletion of IGFBP5 expression also resulted in increased adiposity when the animals were fed a high-fat diet and in the absence of IGFBP5, these animals exhibited glucose intolerance (Gleason et al. 2010). Bach et al. implicated IGFBP5 in diabetic nephropathy progression. They noted that treatment with amino guanidine, which delays the development of diabetic nephropathy in experimental animals resulted in 75\% reduction in IGFBP5 expression; however. they did not directly link this to alteration in kidney function (Bach et al. 2000). Giannini et al. noted that endothelial cells derived from micro vessels of diabetic patients preferentially expressed IGFBP2 and 5 and that adding IGFBP5 with IGF1-stimulated the growth of these cells (Giannini et al. 2001). They speculated that it might be involved in diabetic retinopathy. Arnqvist et al. using large vessel endothelium showed that the VEGF a major stimulant of retinopathy stimulated IGFBP5 expression by the cells (Dahlfors \& Arnqvist 2000). In contrast, in vitro studies in beta cells suggest that IGFBP5 may stimulate their growth. Gleason et al. utilized beta cells transfected with a constituency active form of AKT. They analyzed genes that were preferentially synthesized by proliferating beta cells and noted that IGFBP5 was induced significantly (Gleason et al. 2010).

Human studies have shown that IGFBP5 levels are significantly reduced in both type I and type II diabetic patients and that the degree of reduction correlates with reduction in total IGF1 concentrations (Jehle et al. 1998). Interestingly, IGFBP3 exhibited the same relationship, but there was a negative correlation with IGFBP1 and 2. These findings suggest that the ternary complex components IGF1, IGFBP3 and IGFBP5 are reduced in the presence of diabetes and that these effects are dissociated from the changes in tissue IGFBP5 expression. Studies in humans have shown SNPs that alter IGFBP5 expression are associated with changes in adiponectin concentrations and that IGFBP5 concentrations correlate with adiponectin in women (Kallio et al. 2009). Similarly, analysis of candidate biomarkers for the development of gestational diabetes in pregnancy showed that IGFBP5 was one of four proteins with a high positive predictive value (Zhao et al. 2017).

\section{IGFBP6}

IGFBP6 concentrations are elevated in patients with type I diabetes and the degree of increase correlates with the presence of complications. Patients in the upper quartile were 1.7 times more likely to develop complications than those in the lowest quartile (Sharma et al. 2016).

In summary, IGFBP concentrations are modulated significantly by changes in carbohydrate metabolism. These changes are mediated at the level of protein synthesis and secretion as well as posttranslational modifications and proteolysis. These changes can be secondary to changes in insulin secretion, insulin action or hyperglycemia. The IGFBPs definitely modulate IGF1's ability to alter insulin sensitivity and target cell responsiveness. Definitive determination of the role of the IGFBPs in directly modulating carbohydrate metabolism will require a much more in-depth understanding of how they function to alter cellular responsiveness.

\section{Atherosclerosis}

\section{IGFBP1}

Analysis at the cellular level showed that IGFBP1 can enhance or inhibit the effects of IGF1 on VSMC proliferation. The phosphorylation status of IGFBP1 is a major determinant of the response. Minimally phosphorylated IGFBP1 enhances the ability of IGF1 to stimulate proliferation, whereas heavily phosphorylated IGFBP1 binds to IGF1 and inhibits its interaction with the receptor, thus inhibiting proliferation (Jones \& Clemmons 1995). Human studies suggest that IGFBP1 expressed in lesions can modify atherosclerosis. Gene expression profiles in 164 human carotid plaques demonstrated that IGFBP1 expression was significantly increased compared to unaffected artery, whereas IGF1 expression was unchanged (Wang et al. 2012). IGFBP1 expression was localized to macrophages and smooth muscle cells within these lesions. Expression correlated with IL-1 and IL-6, inflammatory markers whose expression is increased in atherosclerosis. The phosphorylation status was not measured but since expression was increased and phospho IGFBP1 has consistently been shown to inhibit IGF1 action. It is reasonable to assume most of the IGFBP1 in the carotid lesions was not phosphorylated. When plasma concentrations of the different phosphorylated forms of IGFBP1 were measured in 75 subjects, 36 of whom had ischemic heart disease, there was a correlation between low phosphate IGFBP1 and a predisposition to coronary artery disease risk (Borai et al. 2010). The ratio of non-phosphorylated to phosphorylated IGFBP1 was increased 2.5-fold in IHD and receiver-operator characteristic analysis showed a correlation of 0.75 for the 
non-phosphorylated form. These findings are not consistent with the change in total serum IGFBP1 that is suppressed in obese, insulin-resistant subjects who are at increased risk for atherosclerosis (Gibson et al. 1996, Katz et al. 2016). Overexpression of IGFBP1 in obese mice reduced blood pressure and improved insulin sensitivity as well as insulin-stimulated nitric oxide generation. When these mice were crossed with an APOE-/- mice there was reduced development of atherosclerosis (Rajwani et al. 2012). The phosphorylation status of IGFBP1 was not measured in this study, but the results suggest that overexpression resulted in a high concentration of heavily phosphorylate IGFBP1, which would be expected to inhibit the effects of IGF1 on lesion development. Total plasma IGFBP1 levels were positively associated with increased carotid intimal medial thickness in normal weight, healthy adults, but the association was negative in obese type 2 diabetic patients (Leinonen et al. 2002, Boquist et al. 2008). This suggests that defective insulin action may influence the results. Part of the explanation may be that plasma IGFBP1 is derived from endothelium rather than macrophages or smooth muscle cells. The proteinrelated transcriptional enhancer factor-1 (RTEF-1) is an important regulator of angiogenesis (Rubinow \& Bornfeldt 2012). Under normal circumstances, insulin represses the transcription of RTEF-1. RTEF-1 binding to endothelial cells augments IGFBP1 expression. Mice in which RTEF-1 was knocked down in endothelial cells exhibited decreased serum IGFBP1 and had increased insulin resistance during high-fat feeding. RTEF-1 overexpression was associated with enhanced insulin sensitivity in response to highfat feeding and upregulation of IGFBP1. Therefore, loss of RTEF-1 in insulin-resistant states could contribute to lowering IGFBP1. Unfortunately, the phosphorylation status of IGFBP1 was not documented in this study (Messmer-Blust et al. 2012).

In contrast to the long-term follow-up studies wherein low serum IGFBP1 concentrations correlate inversely with increased cardiovascular risk markers, measurement of IGFBP1 during acute coronary events shows that high levels predict increased cardiovascular morbidity and mortality. A recent study of 67 patients with unstable angina showed the absolute value of IGFBP1 predicted critical CAD with the specificity of 0.93 . When combined with HDL values, the sensitivity was 0.82 . The phosphorylation status was not determined (Zheng et al. 2017). Similarly, high IGFBP1 predicted increased risk of mortality in elderly women with the hazard ratio of $3 / 1$ when compared to low IGFBP1 values (Maggio et al. 2013). IGFBP1 after oral glucose is a reflection of insulin sensitivity, and this value correlates directly with increased cardiovascular risk and mortality in elderly nondiabetic adults (Kaplan et al. 2017). In summary, changes in total IGFBP1 (and possibly the non-phosphorylated form) within lesions predispose to lesion development. In contrast patients with multiple risk factors have low serum IGFBP1 but the degree to which this contributes to lesion development is unknown. Patients who develop vascular events have clear changes in IGFBP1 but a mechanism by which IGFBP1 leads to an increased incidence of events has not been identified.

\section{IGFBP2}

As for IGFBP1, IGFBP2 has direct effects on vascular smooth muscle. IGFBP2 binds RPTP $\beta$ expressed on the surface of VSM and stimulates its polymerization resulting in enhanced PTEN tyrosine phosphorylation, thereby reducing its ability to inhibit AKT activation in response to IGF1 (Fig. 3) (Shen et al. 2012). These effects are IGF1 and IGFBP2 dependent and addition of IGFBP2 with IGF1 to VSMC stimulates proliferation. A study of 440 patients with peripheral vascular disease in the lower extremity showed that IGFBP2 was positively and significantly associated with peripheral vascular disease severity (Urbonaviciene et al. 2014). IGFBP2 concentrations were positively associated with a higher mortality rate including cardiovascular mortality even though the subjects had a better metabolic risk profile (van den Beld et al. 2012). A case-control study of 2023 subjects who had undergone coronary angiography showed that in comparison to multiple cardiovascular biomarkers, IGFBP2 was independently directly associated with myocardial infarction in elderly

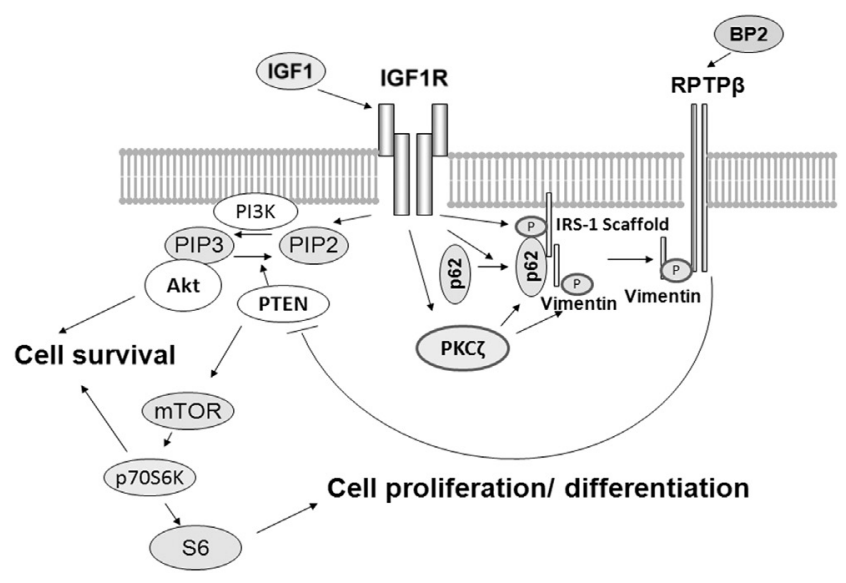

Figure 3

Cooperative signaling by RPTP $\beta$ and IGFBP2 receptor and IGF1. Signals generated by these two receptors converge to activate AKT. 
adults (Halim et al. 2015). As for IGFBP1, there are conflicting epidemiological results for plasma IGFBP2 and atherosclerotic risk with several studies showing an inverse relationship (Ko et al. 2012, Carter et al. 2014, Narayanan et al. 2014). A recent study showed that IGFBP2 correlated inversely with pulse wave velocity and IGFBP2 was significantly lower in type II diabetics who had an increased risk for vascular disease (Olszanecka et al. 2017). An additional study showed that IGFBP2 correlated inversely with the presence of hypertension in perimenopausal women (Hjortebjerg et al. 2017). Overexpression of IGFBP2 in mice protected against obesity and increases in markers of atherosclerotic risk supporting the conclusion that low serum IGFBP2 would predispose to the development of risk factors (Wheatcroft \& Kearney 2009).

In summary, it appears that locally secreted IGFBP2 has effects on vascular smooth muscle that are distinctly different from blood transported IGFBP2, which prior to lesion development appears to be negatively correlated with atherosclerotic risk factors. However, in later stages of lesion development, plasma IGFBP2 correlates directly with increased rates of myocardial infarction and cardiovascular mortality. These findings suggest that IGFBP2 has multi-functional effects on atherosclerotic lesion development and that more research is required to define the basic mechanisms mediating IGFBP2's effects on blood vessel cell types over time to discern the clinical implications.

\section{IGFBP3}

IGFBP3 has been extensively studied in epidemiologic analyses of atherosclerotic risk. Some in vitro studies support the hypothesis that IGFBP3 is functioning in vascular cells to inhibit IGF actions. In endothelium, IGFBP3 inhibits the ability of cytokines such as TNF to induce insulin resistance and early manifestations of atherosclerosis (Mohanraj et al. 2013). It also reduces ENOS and PKC zeta phosphorylation in vascular endothelium in diabetic animals (Zhang et al. 2015). However, in hyperlipidemic rabbits, there was increased IGFBP3 within developing lesions (Hirai et al. 2011). Studies in obese adolescents showed that IGFBP3 correlated directly with blood pressure, fasting insulin and C-reactive protein (Lam et al. 2010). Cross-sectional studies in adults show a positive correlation between IGFBP3 and total and LDL cholesterol and an inverse correlation with HDL (Kawachi et al. 2005, Lam et al. 2010, Eggert et al. 2014).
Several studies have examined the relationship between carotid atherosclerosis and serum IGFBP3 concentrations. Coloa et al. showed that the IGFBP3 $Z$ score and mean IMT were inversely correlated and that IGFBP3 $Z$ scores and IGFBP3 was the second best predictor of IMT after age (Colao et al. 2005). This study was confirmed by Spilcke-Liss et al. who showed that after adjusting for confounding factors IGFBP3 was strongly associated with risk of increased IMT (Spilcke-Liss et al. 2011). In contrast, other studies analyzed hypertensive patients and found that IGFBP3 correlated positively with IMT and systolic blood pressure (Watanabe et al. 2003, Kawachi et al. 2005). Multiple logistic regression analysis revealed that IGFBP3 was positively associated with a 9 fold increase in risk for carotid plaque formation (Watanabe et al. 2003). Analysis by Kawachi et al. showed that IGFBP3 correlated with IMT independently of age, blood pressure and BMI (Kawachi et al. 2005). IGFBP3 is also associated with plaque instability and the relative risk ratio is 1.38 (Martin et al. 2008). In contrast, Kaplan et al. reported that IGFBP3 was inversely associated with a higher risk of nonfatal myocardial infarction (Kaplan et al. 2007). In studies analyzing patients with severe peripheral vascular disease, IGFBP3 concentrations were significantly lower compared to those with less severe disease (Brevetti et al. 2008).

Three studies have analyzed the relationship between IGFBP3 and outcomes. Low IGFBP3 levels predicted an unfavorable stroke outcome (Ebinger et al. 2015) and increased all-cause mortality (HR1.57) (Yeap et al. 2011). This was confirmed by Frederich et al. who showed that low IGFBP3 levels predicted increased cardiovascular mortality (HR 1.92) (Friedrich et al. 2009). In summary, high levels of serum IGFBP3 correlate with worsening metabolic profile as well as the early development of carotid atherosclerosis. In contrast, low IGFBP3 levels correlate with subsequent myocardial infarction and worse functional outcomes following vascular events. One mechanism by which low IGFBP3 might lead to worsening outcomes is the change in IGF1/IGFBP3 ratio. Although IGF1 can stimulate smooth muscle cell proliferation, it inhibits apoptosis and plaque hemorrhage thus an increasing ratio could mediate this beneficial effect. However, none of these studies have measured bioavailable IGF1; therefore, it is not possible to determine if this might provide an explanation.

\section{IGFBP4}

IGFBP4 has generally been classified as a negative regulator of VSMC proliferation, but this effect is dependent upon 
context. VSMC release an IGFBP4 protease that degrades it thereby nullifying its ability to inhibit atherogenesis. Infusion of a protease-resistant mutant into pigs showed that the proliferative response that occurs in response to wounding was significantly inhibited (Nichols et al. 2007). Similarly, transgenic overexpression of PAPP-A, a protease that degrades IGFBP4, in mice accelerated atherosclerotic lesion development (Conover et al. 2010). Knockdown of the protease resulted in some resistance to the development of lesions (Harrington et al. 2007). There is additional supporting data in primates wherein estrogen treatment significantly stimulated the synthesis of IGFBP4 (Eyster et al. 2014). Since estrogen is a protective factor the authors concluded that this may be a mechanism by which estrogen inhibits lesion formation. Epidemiologic studies showed that in type I diabetics serum concentrations of the $\mathrm{N}$-terminal and $\mathrm{C}$-terminal fragments of IGFBP4 were significantly higher in patients with increased cardiovascular mortality suggesting that ongoing proteolysis of IGFBP4 was a risk factor for lesion development (Hjortebjerg et al. 2015). An additional study noted that IGFBP4 fragments were increased in patients with type II diabetes who had abnormal carotid artery remodeling as determined by MRI (Hjortebjerg et al. 2017).

\section{IGFBP5}

At the cellular level, IGFBP5 associates with extracellular matrix and enhances VSMC proliferation in response to IGF1 (Jones et al. 1993b). In contrast if the intact protein is present in the medium in quantities greater than IGF1, it inhibits VSMC proliferation. These effects are due in part to the fact that the affinity of IGFBP5 for IGF1 is lowered by extracellular matrix binding thus allowing IGF1 to be in better equilibration with its receptor. Almquist et al. demonstrated that large vessel endothelial cells from diabetic animals expressed IGFBP5 and that its synthesis could be stimulated by angiotensin-II, TGF-beta and VEGF (Dahlfors \& Arnqvist 2000). Levels of IGFBP5 expression in VSM were found to be higher in SHR rats as compared to WKY and these rats have increased VSMC proliferation (Lee et al. 2013). Treatment of WKY rats with IGFBP5 increased IGFBP5 expression in VSM and further stimulated VSM proliferation. Incubation with angiotensin-II or IGF1 increased IGFBP5 transcription and siRNA transfection reduced VSMC proliferation (Lee et al. 2013). Pitvistatin inhibited IGFBP5 production in parallel with decreasing proliferation and migration (Ha et al. 2015).
Epidemiologic studies showed that high concentrations of IGFBP5 were present in 95 male patients with CAD as compared to age-matched controls who did not have CAD (Fischer et al. 2004). Following multi-variant analysis, IGFBP3, 5 and IGF1 were associated with the presence of CAD. Therefore, all of these studies support the conclusion that IGFBP5 is functioning to enhance IGF1's anabolic effects on VSMC.

\section{Bone metabolism}

The role of IGFBPs in regulating bone metabolism has been analyzed directly in vitro using osteoblast and osteoclast cultures, in genetically manipulated mouse models and indirectly in human studies. In general, in vitro studies have demonstrated that if an IGFBP is added in excess of IGF1 or II, their effects on osteoblast proliferation can be inhibited. Similar results have been generated for some forms of IGFBPs in inhibiting osteoblast differentiation and some forms have been shown to alter osteoclast differentiation. In vivo studies have been conducted using animals in which a form of IGFBP is overexpressed or knocked down and some studies have utilized direct injection of IGFBPs into bone or bone matrix.

\section{IGFBP1}

In vitro analysis showed that IGFBP1 was produced by human osteoblasts and that its production was stimulated by glucocorticoids and inhibited by insulin (Okazaki et al. 1994). Since glucocorticoids negatively regulate osteoblast division and mineralization, this was interpreted to mean that IGFBP1 was inhibiting the actions of IGF1. Similarly adding IGFBP1 to growth plate chondrocytes resulted in inhibition of cellular proliferation (Kiepe et al. 2002). During hypoxemia, which inhibits mineralization, IGFBP1 was induced significantly, and this was mediated by $\mathrm{HIF} \alpha-1$.

In heterochromatin-1-knockout mice that have significant dwarfism, there is a fourfold increase in IGFBP1 suggesting that it is inhibiting IGF1 stimulation of bone size (Garfinkel et al. 2015). Forced overexpression of IGBP-1 in transgenic mice has given variable results; however, significant overexpression resulted in growth retardation and delayed mineralization (Kadaba et al. 1995). A recent paper demonstrated that FGF-21, which induces bone loss in experimental animals increased IGFBP1 production by the liver and administration of an anti-IGFBP1 antibody attenuated the bone loss that was induced by FGF-21 (Wang et al. 2015). 
Human studies showed that serum levels of IGFBP1 were increased 4.1-fold in patients with idiopathic osteoporosis, and this occurred concomitantly with a 73\% decrease in free IGF1 (Jehle et al. 2003). Analysis of IGFBP1 in IUGR twins showed increased levels correlated positively with markers of bone resorption and negatively with PINP a marker of bone formation (Bajoria et al. 2006). Analysis of the femoral neck bone mineral density (BMD) in elderly Swedish men showed a negative correlation with bone mineral density $(R=-0.37)$ (Gillberg et al. 2002). Similarly IGFBP1 elevations were associated with increased fracture risk in 351 elderly women $(\mathrm{HR}=1.46)$ (Lundin et al. 2016). Bone histomorphometry analysis in 51 men with idiopathic osteoporosis showed that osteoid thickness correlated with the IGF1/IGFBP1 ratio. However, IGFBP1 was not shown to be an independent predictor of BMD in two other studies (Jassal et al. 2005, Pye et al. 2011). Taken together, the results support the conclusion that high serum IGFBP1 concentrations inhibit bone acquisition.

\section{IGFBP2}

Analysis of dental pulp cells showed that during differentiation IGFBP2 is upregulated and studies that analyzed temporal expression showed that abundant amounts were present in mid-differentiation (Alkharobi et al. 2016). Palermo et al. demonstrated that IGFBP2 plus IGF2 stimulated osteoblast differentiation as assessed by induction of alkaline phosphatase (Palermo et al. 2004). IGFBP2 undergoes proteolytic cleavage in extracellular fluids and a C-terminal fragment containing amino acids 167-289 stimulated proliferation of growth plate chondrocytes (Kiepe et al. 2015). Other studies show that if IGFBP2 associates with extracellular matrix and an equimolar concentration of IGF2 is added, IGFBP2 potentiates the effect of IGF2 on osteoblast differentiation (Conover \& Khosla 2003). Additional studies suggest that IGFBP2 also stimulates osteoblast precursors. Expression of IGFBP2 in inducible brown adipose tissue enhanced osteoblast function and its depletion resulted in decreased osteoblast activity (Rahman et al. 2013). IGFBP2 interacts with the alpha 5 integrin in mesenchymal stem cells to stimulate osteogenic differentiation (Hamidouche et al. 2010). The anabolic role of IGFBP2 in osteoblast differentiation has recently been confirmed in both MC-3T3 cells and primary calvarial osteoblast cultures and its effects are mediated through induction of AMP kinase (Xi et al. 2016). Stimulation of differentiation is mediated through the cell surface receptor RPTP $\beta$ and concomitant engagement of RPTP $\beta$ and the IGF1 receptor enhances the response (Shen et al. 2015).

Studies in animals have confirmed these findings. The infusion of equimolar concentrations of IGF2 and IGFBP2 to rats using the hindlimb suspension model showed that this complex stimulated bone formation (Conover et al. 2002). Similarly, ovariectomy, which is associated with loss of bone mineral, results in decreased serum IGFBP2 (DeMambro et al. 2015). Paradoxically, overexpression of IGFBP2 alone is associated with decreased BMD; however, under those circumstances, there is no concomitant increase in IGF1 and in vitro models wherein excess IGFBP2 is added without IGF1 show inhibition of osteoblast proliferation and ECM synthesis (Hoeflich et al. 1999). The mechanism underlying the requirement of concomitant exposure to IGF1 for IGFBP2 to be anabolic has been delineated. The ability of RPTP $\beta$ to inactivate PTEN requires stimulation of the IGF1 receptor. This effect requires RPTP $\beta$ binding to phosphorylated vimentin and IGF1 receptor activation stimulates vimentin phosphorylation (Fig. 3) (Shen et al. 2015). Therefore, failure to engage the IGF1 receptor results in refractoriness to IGFBP2 stimulation. The anabolic role of IGFBP2 has received further support from gene deletion studies. Knockdown of IGFBP2 yielded an important phenotype that was distinctly different from that noted with IGFBP2 overexpression (DeMambro et al. 2008). These mice had a $40 \%$ reduction in trabecular BMD at age 16 weeks and decreased femur length as well was decreased osteocalcin expression. Subsequent studies showed that IGFBP2 stimulated osteoblast proliferation in IGFBP2 -/- mice, and it stimulated differentiation of preosteoblasts derived from these mice in vitro (Kawai et al. 2011).

Serum IGFBP2 concentrations peak during puberty concomitantly with IGF1 at the time of the maximal growth spurt. In contrast, major increases in IGFBP2 in the absence of a concomitant increase in IGF1 that occur in normal aging are associated with increases in bone turnover and bone loss (Amin et al. 2007). Very high IGFBP2 concentrations that occur in normal adults over 75 years correlate inversely with decreased BMD in the proximal femur (van den Beld et al. 2012). Other studies showed older patients with osteoporosis had an inverse correlation between IGFBP2 and BMD (Lebrasseur et al. 2012). Importantly, most of these studies did not analyze IGF1 and IGFBP2 as independent variables. Similarly, in patients with anorexia nervosa who have very low levels of serum IGF1, there is an inverse relationship between 
IGFBP2 and BMD (Grinspoon et al. 2003). Since their actions are interdependent, the results clearly support the conclusion that IGFBP2 functions in bone are IGF1 dependent.

\section{IGFBP3}

Growth plate chondrocytes and primary osteoblasts secrete IGFBP3 (Malpe et al. 1997, Kiepe et al. 2005). Most in vitro studies support the hypothesis that IGFBP3 inhibits IGF1 stimulation of osteoblast proliferation. Specifically adding purified protein but not mutants that do not bind IGF1 inhibits cell division (Schmid et al. 1995). Additionally, culture conditions, such as hypoxia that stimulate IGFBP3, inhibit the differentiation of adipose-derived stem cells into osteoblasts (Kim et al. 2016). Conversely, other studies show that once osteogenic commitment has occurred agents such as TGFbeta and vitamin $\mathrm{D}$ stimulate osteoblast differentiation via stimulation of IGFBP3 (Kveiborg et al. 2002). Recently matrix-associated IGFBP3 was found to localize IGF1 and the combination of matrix IGFBP3 plus IGF1 resulted in enhancement of IGF1-stimulated bone formation (Xian et al. 2012). This conclusion is consistent with in vitro studies, which showed that if IGFBP3 was added to osteoblasts then removed and IGF1 added subsequently, there was a greater response to IGF1 following pre-IGFBP3 incubation (Ernst \& Rodan 1990).

In vivo studies show that if IGFBP3 is overexpressed it inhibits IGF1 action both in terms of osteoblast proliferation and bone formation (Silha et al. 2003). IGFBP3 overexpression was also found to inhibit BMP-2 stimulated differentiation in vivo (Zhong et al. 2011). In contrast, administration of recombinant IGF1 with IGFBP3 in equimolar concentrations improved osteopenia in rats following ovariectomy or bilateral sciatic neurectomy suggesting that the effect of overexpression of IGFBP3 alone was due to attenuation of IGF1 actions (Narusawa et al. 1995). An additional study showed this combination increased bone formation rate in lumbar vertebra of ovariectomized rats (Bagi et al. 1994). Direct injection of IGF1 plus IGFBP3 complex into bone resulted in localization of IGF1 in matrix and stimulated new bone formation as well as osteoblast differentiation (Xian et al. 2012). Mutagenesis of IGFBP3 resulting decreased matrix binding resulted in an inability of the injected IGF1 to enhance bone formation. Estrogen administration to ovariectomized monkeys induces IGFBP3 and administration of growth hormone increases IGFBP3 synthesis in bone in parallel with IGF1 (Ham et al. 2004, DiGirolamo et al. 2007). Similarly, PTH infusion enhances IGF1 induction of IGFBP3 and this response is attenuated in inflammatory conditions associated with decreased bone formation (Johansson et al. 1994).

Knockdown of IGFBP3 alone did not yield a specific bone phenotype however the combined knockdown of IGFBP3, 4 and 5 in mice reduced bone size but did not change BMD (Ning et al. 2006). This effect is likely mediated by reduction in the ternary complex of IGFBP3/5, ALS and IGF1. This conclusion is supported by studies which show that knockdown of ALS reduces the amount of IGF1 or in the ternary complex in serum and results in specific bone phenotype. ALS knockout mice have reduced bone size and BMD (Yakar et al. 2009). Administration of growth hormone does not increase growth or BMD, although there is a small increase in cross-sectional area in cortical bone (Kennedy et al. 2014). Ablation of ALS in mice over expressing growth hormone showed decreased skeletal size and trabecular bone (Liu et al. 2017).

Human studies have shown that postmenopausal women with increased risk of vertebral fractures have decreased IGFBP3 compared to women without fractures (Yamaguchi et al. 2006). Similarly postmenopausal women with low BMD had significantly lower levels compared to controls with normal BMD (Kim et al. 1999). Femoral neck osteoporosis was associated with lower levels of serum IGFBP3 however IGF1 and II were also reduced (Boonen et al. 1999). In older men higher levels of IGF1 and IGFBP3 were associated with higher BMD. In elderly man with idiopathic osteoporosis IGFBP3 was $46 \%$ lower than controls whereas, IGF1 levels were similar (Johansson et al. 1997). Pathophysiologic conditions such as chronic hepatitis $\mathrm{C}$ and inflammatory bowel disease are associated with decreased BMD and IGFBP3 (Raslan et al. 2010). Subjects that carry ALS mutations that reduce serum IGFBP3 have significantly lower BMD (Högler et al. 2014).

In summary, systemic administration of IGFBP3, its enhanced production in bone or increased matrix association in the presence of adequate IGF1 is associated with a positive anabolic response. In contrast, conditions wherein there is high IGFBP3 and no concomitant change in IGF1 there is decreased bone formation as well as increased resorption. Therefore, the critical determinants of the response appear to be the stage of bone cell differentiation, the site of production, the ratio between IGF1/IGFBP3 and whether or not the IGFBP3 is associated with extracellular matrix. 


\section{IGFBP4}

Analysis of osteoblasts in vitro has shown that these cells synthesize and secrete IGFBP4 (Amarnani et al. 1993). Initial studies concluded that IGFBP4 inhibited osteoblast proliferation and differentiation. Several factors that alter bone physiology including estrogen and vitamin D stimulate IGFBP4 synthesis (Scharla et al. 1993, Kassem et al. 1996). Factors that stimulate osteoblast differentiation such as, osteogenic protein-1 inhibit its synthesis (Yeh et al. 1997). Therefore it was concluded that IGFBP4 functions primarily as an inhibitor of differentiation and bone formation. Studies by Mohan and coworkers demonstrated that the addition of IGFBP4 in vitro inhibited IGF1 binding to its receptor and osteoblast proliferation (Mohan et al. 1995). Furthermore they showed that a protease secreted by osteoblasts cleaved IGFBP4 allowing IGF1 access to the receptor and alleviating IGFBP4 inhibition of IGF1-stimulated proliferation. They showed that IGFBP4 proteolysis was enhanced by the addition of IGF1 (Qin et al. 1999).

Transgenic overexpression of IGFBP4 specifically in osteoblasts resulted in marked inhibition of bone formation and global growth retardation (Zhang et al. 2003). Administration of IGFBP4 locally into bone in normal mice inhibited of IGF1 stimulated bone formation, however, when it was given systemically there was an increase in bone formation markers (Miyakoshi et al. 1999). A follow-up study revealed that systemic administration could increase bone formation parameters due to proteolysis of IGFBP4 since infusion of a proteaseresistant form did not alter these markers (Miyakoshi et al. 2015). The role of proteolysis was further confirmed in transgenic mice overexpressing PAPP-A, a protease known to degrade IGFBP4. Bone formation was enhanced in these mice as was BMD (Clifton \& Conover 2001). PAPP-A knockout mice had decreased bone size and BMD. In diabetic mice with severe osteopathy there is a significant decrease in serum IGF1 associated with an increase in intact IGFBP4 and reduced proteolysis which favors its sequestration (Ahmad et al. 2008). These findings suggest that IGFBP4 is sequestering IGF1 and eliminating its ability to stimulate osteoblastogenesis.

IGFBP4 deletion in mice results in a decrease in bone size however initial studies reported no change in BMD. A recent paper is revealed a complex mechanism by which IGFBP4 regulates skeletal growth in female mice during puberty (Maridas et al. 2017). This effect was sex specific. Both sexes showed reduce size at birth however between 8 and 16 weeks female mice showed a significant reduction in the rate of acquisition of BMD compared to male mice. This effect was noted to be due to increased osteoclast number and osteoclastogenesis suggesting that IGFBP4 negatively regulates osteoclast number and activity in female mice. Notably the induction of IGFBP4 has been shown to be estrogen dependent therefore this may be an important function of IGFBP4 during normal female pubertal development.

Human studies have shown that IGFBP4 levels are increased in postmenopausal females but serum concentrations do not correlate with femoral neck BMD (Karasik et al. 2002). A second study demonstrated a correlation with PTH levels but again there was no significant correlation between increasing IGFBP4 during aging and decreasing BMD (Mohan \& Baylink 1997). Additional studies demonstrated that growth hormone increased IGFBP4 and that at baseline IGFBP4 correlated with BMD but the change in IGFBP4 did not predict an increase in bone mass in response to growth hormone (Thorén et al. 1998). In summary, IGFBP4 directly inhibits IGF1 action on bone but high concentrations serve as a reservoir for IGF and exposure to proteases, such as PAPP-A, may result in high IGFBP4 concentrations being associated with an increase in osteoblast function.

\section{IGFBP5}

Several in vitro studies have proposed that IGFBP5 is an important trophic factor for bone. Analysis of aged osteoblast cultures showed that they produce less IGFBP5 as their regenerative capacity decreases (Kveiborg et al. 2000). Local application of IGFBP5 to mesenchymal stem cells in which IGFBP5 synthesis had been deleted restored osteoblast function and the ability to differentiate (Han et al. 2017). Treatment of osteoblasts with IGFBP5 in vitro enhanced alkaline phosphatase activity and cell proliferation (Andress \& Birnbaum 1992). IGFBP5 expression was shown to be upregulated in growth plate chondrocytes during differentiation and overexpression rescued osteoblasts from apoptosis whereas exogenous addition facilitated cell death (Yin et al. 2004, Kiepe et al. 2006). IGFBP5 binds to hydroxyapetite and this localizes IGF1 in bone (Campbell \& Andress 1997). A carboxyl terminal fragment of IGFBP5 that bound IGF1 with reduced affinity stimulated mitogenesis of osteoblasts and enhanced the response to IGF1 (Andress et al. 1993). Furthermore IGF1 itself stimulates IGFBP5 synthesis (Gabbitas \& Canalis 1998). In contrast direct addition of IGFBP5 inhibited the ability of BMP -2 to induce osteoblast 
differentiation and this effect was reduced if a mutant which bound IGF1 poorly was utilized (Mukherjee \& Rotwein 2008). The addition of IGFBP5 in vitro was shown to inhibit vitamin $\mathrm{D}$ induced osteoblast differentiation (Schedlich et al. 2007). An additional study demonstrated that osteoblast-derived IGFBP5 negatively regulates bone accretion by stimulating osteoclast formation and activity (Kanatani et al. 2000). In part these paradoxical findings may be explained by the observation that IGFBP5 knockdown in vitro enhanced osteoblast apoptosis which was rescued by IGFBP5 induction but not by exogenous addition (Yin et al. 2004).

The importance of IGF1 stimulated IGFBP5 is emphasized by study in which heterozygous knockout IGF1 mice were found to have low IGFBP5 levels but following IGF1 administration this mRNA was specifically induced in osteoblasts. IGF1 also increased BMD and cortical thickness (Guerra-Menéndez et al. 2013). In vivo studies have shown that administration of equimolar amounts of IGF1 and IGFBP5 enhances cortical bone formation and BMD in mice (Bauss et al. 2001). Studies in IGF1 knockout mice showed that direct injection of IGFBP5 into bone stimulated calvarial bone mass accumulation (Miyakoshi et al. 2001). IGFBP5 binds avidly to extracellular matrix, therefore, it was postulated that the effects of direct injection are due to matrix association, thereby providing a slow release mechanism of IGF1. Administration of IGFBP5 to ovariectomized mice enhanced bone formation compared to OVX controls (Andress 2001). In contrast, osteoblast specific overexpression of IGFBP5 in transgenic mice resulted in a small degree of inhibition of bone mineral apposition that was transient (Devlin et al. 2002). In a separate experiment more intense overexpression that increased serum levels eight fold resulted in a 30\% decrease in BMD (Salih et al. 2005). Knockdown of IGFBP5 did not result in a bone phenotype. However IGFBP5 knockdown was accompanied by an increase in IGFBP3 which could compensate for its loss in bone matrix as well as reduced ternary complex formation.

Human studies show that serum IGFBP5 declines with age and bone content decreases. Serum IGFBP5 correlates positively with femoral neck BMD. In osteoporotic patients there was a 52\% reduction in IGFBP5 compared to controls (Jehle et al. 2003).

\section{IGFBP6}

IGFBP6 has been studied minimally in osteoblasts but it is believed to be a negative regulatory factor. Direct addition of IGFBP6 to osteoblast cultures inhibits osteoblast differentiation and the protein decreases during osteoblast differentiation in vitro (Strohbach et al. 2008). Similarly cortisol which inhibits osteoblast differentiation stimulated IGFBP6 synthesis (Gabbitas \& Canalis 1996). Analysis of nonunion fractures revealed that IGFBP6 synthesis was increased compared to control fractures and serum levels of IGFBP6 were increased 2.1 fold in adults with osteoporosis compared to age matched controls (Koh et al. 2011).

\section{Skeletal muscle metabolism}

\section{IGFBP1}

As for other body tissues both locally secreted IGFBPs and IGFBPs transported in the circulation regulate the development of muscle mass and its maintenance during pathophysiologic states. IGFBP1 is not synthesized in skeletal muscle but addition of IGFBP1 to myoblast cultures inhibits IGF1 stimulated protein synthesis (Frost \& Lang 1999) and catabolic factors such as IL-1 stimulate IGFBP1 synthesis in liver in association with increased muscle breakdown (Cooney et al. 1999). Other catabolic stimuli such as TNF alpha IL-6, burn injury, alcohol and undernutrition stimulate IGFBP1 synthesis in liver resulting in accumulation of IGFBP1 in muscle (Fan et al. 1995, Gautsch et al. 1998, Lang et al. 2000, 2004). Infusion of IGFBP1 into rats inhibited basal and IGF1 stimulated muscle protein synthesis. Protein synthesis declined 20\% when IGFBP1 increased 2-3 fold (Lang et al. 2003). This effect was muscle specific since protein synthesis rates did not decline in liver, kidney or heart. Transgenic overexpression was accompanied by reduced muscle mass and myostatin-knockout mice, which have increased muscle mass have suppressed IGFBP1 (Murphy 2000, Williams et al. 2011). Human studies show that serum concentrations correlate negatively with muscle mass. Older women who had higher IGFBP1 were catabolic and had low muscle mass compared to those who were obese and had suppressed IGFBP1 (Stilling et al. 2017).

\section{IGFBP2}

IGFBP2 is synthesized by both satellite cells (Ernst et al. 1996) and skeletal myoblasts (Rousse et al. 1998). High levels are present during proliferation and decline during differentiation (Rousse et al. 1998, Crown et al. 2000). Stewart and coworkers proposed that the actions of IGFBP2 were biphasic since addition of an IGFBP2 antibody early in the process facilitated differentiation but addition at a later phase inhibited differentiation (Sharples et al. 2013). 
Overexpression of IGFBP2 in transgenic mice resulted in generalized growth inhibition. Administration of growth hormone to these mice resulted in less of an increase in muscle mass compared to controls (Rehfeldt et al. 2010). Muscle-specific overexpression was accompanied by a slower phenotype but no atrophy (Swiderski et al. 2016). This was associated with an increase in glycolytic metabolism. During pathophysiologic states such as the induction of diabetes or fasting in experimental animals expression of IGFBP2 in muscle decreases (Grzelkowska-Kowalczyk et al. 2013). In models of catabolic muscle wasting IGFBP2 expression is down regulated but upregulated during hypertrophy that occurs during the recovery phase after refeeding (Fuentes et al. 2015). Mechanical loading is associated with upregulation of IGFBP2 in association with IGF1 (Player et al. 2014). In elderly humans with reduced appendicular muscle mass and reduced BMD IGFBP2 is increased but these patients have low IGF1 therefore it is difficult to ascertain whether the effect is simply due to reducing free IGF1 further or a change in the IGF1/IGFBP2 complex (Amin et al. 2007, Lebrasseur et al. 2012). In summary, the studies support the conclusion that IGFBP2 can enhance IGF1 stimulated differentiation but the ratio between IGF1 and IGFBP2 ultimately determines the response.

\section{IGFBP3}

In vitro studies of IGFBP3 show that direct addition of IGFBP3 suppresses IGF1 stimulated myoblast proliferation but it also has effects that are IGF1 independent (Pampusch et al. 2003). Additionally WNT, a known inhibitor of cardiac muscle stem cell proliferation, exerts its inhibitory effect through induction of IGFBP3 (Oikonomopoulos et al. 2011). In contrast, Foulstone et al. reported that IGFBP3 synthesized by myoblasts in culture stimulated differentiation (Foulstone et al. 2003). In vivo IGFBP3 expression increases transiently in skeletal muscle during repair and after ischemic injury and these changes occur in muscle associated macrophages (Jennische \& Hall 2000). IGF1 injection into muscle increases IGFBP3 synthesis in female rats but it decreased in males (Oliver et al. 2005). Administration of nandrolone, a potent anabolic, was associated with a 69\% increase in IGFBP3 and a 50\% increase in IGF1 (Lewis et al. 2002). Transgenic overexpression of IGFBP3 in mice did not increase muscle mass. When the complex of IGF1 and IGFBP3 was administered to rats made catabolic by hind limb suspension, it enhanced muscle mass accumulation and inhibited breakdown (Zdanowicz \& Teichberg 2003).
Svanberg et al. showed that administration of this complex to nutritionally compromised rats increased muscle protein synthesis whereas administration of IGF1 alone did not (Svanberg et al. 2000). Booth et al. demonstrated that loading skeletal muscle enhanced IGFBP3 expression and aging was associated with a reduced expression response. Hind limb immobilization resulted in diminished IGFBP3 expression which increased during the recovery phase and these changes occurred primarily in type I fibers (Spangenburg et al. 2003).

Studies in humans show that normal diurnal variation in IGFBP3 correlates with changes in myogenic index and muscle fiber diameter (Burley et al. 2016). In resistancetrained athletes there is a greater increase in IGFBP3 if LVH was present compared to controls and this change in IGFBP3 was speculated to be related to the increased ventricular hypertrophy (Żebrowska et al. 2013). In Chinese elderly and IGFBP3 SNPs that resulted in lower serum IGFBP3 were associated with reduced skeletal muscle mass (Yang et al. 2015). Administration of the IGF1/ IGFBP3 complex to elderly hip fracture patients improved muscle strength (Boonen et al. 2002). In summary, IGFBP3 appears to correlate with anabolic changes. Since excess IGFBP3 suppresses myoblast proliferation in vitro these changes are presumably due to concomitant increases in IGF1 which are necessary to promote skeletal muscle protein synthesis.

\section{IGFBP4}

IGFBP4 is expressed in skeletal muscle cells in vitro and it increases with differentiation (Ewton \& Florini 1995). However forced overexpression inhibits differentiation (Damon et al. 1998). Direct addition to myoblast cultures inhibited IGF1 stimulated proliferation and differentiation (Ewton et al. 1998). In vivo studies in general have supported the conclusion that IGFBP4 inhibits IGF1 stimulated skeletal muscle proliferation and differentiation. IGFBP4 abundance was noted increase in muscle in aging mice (Oliver et al. 2005). Similarly nandrolone administration to rats which resulted in diaphragmatic hypertrophy decreased IGFBP4 expression by $40 \%$ (Lewis et al. 2002). Transgenic overexpression of PAPP-A which decreased intact IGFBP4 increased muscle mass in mice (Rehage et al. 2007). Protein restriction in rats during fetal development led to increased IGFBP4 expression in muscle (Bayol et al. 2004) and infusion of IL-6 which inhibits muscle growth during development increased IGFBP4 (Bodell et al. 2009). Denervation of muscle results in a rapid upregulation of IGFBP4 transcripts 
(Bayol et al. 2000). In contrast, following skeletal muscle injury IGFBP4 expression was increased in connective tissue cells but not regenerating muscle cells during the period of rapid regeneration (Jennische \& Hall 2000). Similarly the presence of diabetes or fasting which are catabolic resulted in decreased IGFBP4 expression which was restored with refeeding (Grzelkowska-Kowalczyk et al. 2013). Administration of clenbuterol which caused a 13\% increase in soleus muscle mass in rats resulted in an 8 fold increase in IGFBP4 mRNA (Awede et al. 2002). Blocking Torc-1 activation in muscle which results in atrophy resulted in downregulation of expression of IGFBP4 (Fuentes et al. 2015). Skeletal muscle loading resulted in a 15\% hypertrophy, a 60\% increase in IGF1 and doubling of IGFBP4 mRNA (Awede et al. 1999). These results suggest that catabolic states increase IGFBP4 and decrease IGF1 whereas, during muscle hypertrophy there are increases in both proteins. These observations lead to the conclusion that IGFBP4 is anabolic in muscle if it is associated with a concomitant increase in IGF1 whereas, an increase in IGFBP4 alone results in a catabolic response.

Studies in humans have shown that the elderly have increases in serum IGFBP4 accompanied by declining IGF1 (Mohan \& Baylink 1997, Karasik et al. 2002, Jehle et al. 2003). In contrast, testosterone injection increased IGF1 and IGFBP4 mRNA in skeletal muscle (Bamman et al. 2001). Exercise decreased in serum IGFBP4 concentrations but levels in muscle were not evaluated (Rosendal et al. 2002). Administration of prednisolone inhibited IGFBP4 proteolysis in muscle suggesting that free IGF1 release was impaired (Ramshanker et al. 2017). Based on the human studies it has been difficult to assign a definitive role for IGFBP4 in muscle cell hypertrophy. It has been proposed that increased IGFBP4 increases the supply of available IGF1 and if sufficient proteolytic activity is present this results in enhanced free IGF1 bioavailability and an anabolic response.

\section{IGFBP5}

IGFBP5 is expressed by skeletal myoblasts in culture and antisense RNA studies indicate that loss of IGFBP5 expression alters the timing of differentiation (Ewton et al. 1998). Expression in primary myoblasts increases during differentiation, however, there are conflicting data regarding its functional role in muscle. Over expression in cultured myoblasts inhibited myoblast differentiation and addition of exogenous IGF1 restored it. Antisense experiments suggested the main function was to properly time the response to IGF1 (James et al. 1996). Addition of purified IGFBP5 inhibits differentiation but addition of IGF analogs that do not bind restores it (Pampusch et al. 2005, Mukherjee et al. 2008). Other investigators have noted that IGFBP5 is necessary for myoblast survival (Meadows et al. 2000). Ren and coworkers demonstrated that knockdown of IGFBP5 impaired mitogenesis and suppressed IGF2 expression (Ren et al. 2008). They determined that IGFBP5 had to bind IGF2 in order for differentiation to occur and in the absence of IGFBP5 there was minimal IGF2 expression. Exogenous addition of IGFBP5 to knockdown cells restored IGF2 production and differentiation. They proposed this feedback loop was required. This intricate requirement probably explains much of the conflicting data. Exposure of muscle cells to high glucose decreased IGFBP5 and inhibited differentiation (GrzelkowskaKowalczyk et al. 2013). Inhibition of differentiation using TNF alpha could be partially rescued by omega-3 fatty acids which induced IGFBP5 expression (Saini et al. 2017).

In general in vivo studies have confirmed the in vitro observations. Dai et al. reported that IGFBP5 is expressed highly in myotomes during early development and suggested that it is important for early myogenic accumulation (Dai et al. 2009). Transgenic mice with a high level of IGFBP5 overexpression in early development had compromised muscle development (Salih et al. 2005). IGFBP5 knockout mice had no development abnormalities in muscle but compensatory changes in other IGFBPs were present (Ning et al. 2007). IGFBP3, 4, 5 knockout mice showed significant reduction in quadriceps muscle volume (Ning et al. 2006). During regeneration following injury there is increased expression of IGFBP5 in muscle (Jennische \& Hall 2000). Cast immobilization significantly reduces IGFBP5 and reambulation is accompanied by an increase (Stevens-Lapsley et al. 2010). Sepsis downregulates IGFBP5 expression in muscle (Lang et al. 2006) as does malnutrition (Safian et al. 2012). In contrast mechanical loading decreases IGFBP5 expression but it increases IGF1 (Bodell et al. 2009, Player et al. 2014). The results are consistent with the conclusion that local IGFBP5 generation in conjunction with IGF1 increase stimulates an anabolic response and that catabolic conditions reduce its expression. However the response to loading is not consistent with that model and suggests that following loading IGFBP5 inhibits the anabolic response to IGF1.

\section{IGFBP6}

IGFBP6 appears to regulate stem cell differentiation into muscle cells. Placental mesenchymal stem cells were forced to differentiate into muscle cells and the addition 
of IGFBP6 enhanced their differentiation (Aboalola \& Han 2017). Silencing IGFBP6 decreased differentiation suggesting an important role in muscle cell commitment. Both age and gender have been shown to regulate IGFBP6 expression by muscle and IGFBP6 was specifically decreased in females during aging in mice (Oliver et al. 2005). In models of regeneration following injury IGFBP6 was shown to be expressed in muscle cells during regeneration along with IGFBP5 (Jennische \& Hall 2000).

\section{Summary and conclusions}

The IGFBPs function coordinately with the IGFs to regulate metabolic adaptations to changes in nutrition, stress and underlying disease states. Since the actions of the IGFs and insulin are interdependent, the IGFBPs indirectly influence insulin actions. Initially, viewed through the narrow focus of regulating IGF access to receptors the field of IGFBP research has been significantly expanded by new discoveries of IGFBP effects that are independent of their ability to bind IGFs. Many of these studies indicate that this area of investigation will provide explanations for cell type and tissue-specific actions of the IGFs and for a better understanding of how various tissue responses to these factors are coordinated. Additionally, since IGFBP synthesis and degradation can be regulated independently of the IGFs, some findings suggest that these experimental approaches will shed new light on the mechanism of how other important metabolic hormones that have major effects on metabolism, such as glucocorticoids or estrogen, influence IGF responsiveness. A major future need is for identification of the receptors and cellular proteins that bind to individual forms of IGFBPs and the signaling systems that are activated following these interactions. This information will be very useful in designing new therapeutic strategies for altering IGF actions in disease states. Overall, future IGFBP research is likely to continue to provide unique insights into understanding the role of this family of proteins in regulating the response to changes in the metabolic milieu.

\section{Declaration of interest}

Dr Clemmons is the guarantor of this review and as such has full access to all reported studies and takes full responsibility for the integrity of an accuracy of the review.

\section{Funding}

This work was supported by a grant from the National Institutes of Health AG-02331.

\section{References}

Aboalola D \& Han VKM 2017 Insulin-Like growth factor binding protein- 6 alters skeletal muscle differentiation of human mesenchymal stem cells. Stem Cells International 20172348485. (https://doi.org/10.1155/2017/2348485)

Ahmad T, Ugarph-Morawski A, Lewitt MS, Li J, Sääf M \& Brismar K 2008 Diabetic osteopathy and the IGF system in the Goto-Kakizaki rat. Growth Hormone and IGF Research 18 404-411. (https://doi. org/10.1016/j.ghir.2008.02.003)

Alkharobi H, Alhodhodi A, Hawsawi Y, Alkafaji H, Devine D, El-Gendy R \& Beattie J 2016 IGFBP2 and -3 co-ordinately regulate IGF1 induced matrix mineralisation of differentiating human dental pulp cells. Stem Cell Research 17 517-522. (https://doi.org/10.1016/j. scr.2016.09.026)

Amarnani S, Merriman HL, Linkhart TA, Baylink DJ \& Mohan S 1993 Autocrine regulators of MC3T3-E1 cell proliferation. Journal of Bone and Mineral Research 8 157-165. (https://doi.org/10.1002/ jbmr.5650080206)

Amin S, Riggs BL, Melton LJ 3rd, Achenbach SJ, Atkinson EJ \& Khosla S 2007 High serum IGFBP2 is predictive of increased bone turnover in aging men and women. Journal of Bone and Mineral Research 22 799-807. (https://doi.org/10.1359/jbmr.070306)

Andress DL 1998 Insulin-like growth factor-binding protein-5 (IGFBP5) stimulates phosphorylation of the IGFBP5 receptor. American Journal of Physiology 274 E744-E745

Andress DL 2001 IGF-binding protein-5 stimulates osteoblast activity and bone accretion in ovariectomized mice. American Journal of Physiology-Endocrinology and Metabolism 281 E283-E288. (https://doi. org/10.1152/ajpendo.2001.281.2.E283)

Andress DL \& Birnbaum RS 1992 Human osteoblast-derived insulin-like growth factor (IGF) binding protein-5 stimulates osteoblast mitogenesis and potentiates IGF action. Journal of Biological Chemistry 267 22467-22472.

Andress DL, Loop SM, Zapf J \& Kiefer MC 1993 Carboxy-truncated insulin-like growth factor binding protein-5 stimulates mitogenesis in osteoblast-like cells. Biochemical and Biophysical Research Communications 195 25-30. (https://doi.org/10.1006/bbrc.1993.2004)

Aneke-Nash CS, Parrinello CM, Rajpathak SN, Rohan TE, Strotmeyer ES, Kritchevsky SB, Psaty BM, Bůžková P, Kizer JR, Newman AB, et al. 2015 Changes in insulin-like growth factor-I and its binding proteins are associated with diabetes mellitus in older adults. Journal of the American Geriatrics Society 63 902-909. (https://doi.org/10.1111/ jgs.13390)

Aneke-Nash CS, Xue X, Qi Q, Biggs ML, Cappola A, Kuller L, Pollak M, Psaty BM, Siscovick D, Mukamal K, et al. 2017 The association between IGF-I and IGFBP3 and incident diabetes in an older population of men and women in the Cardiovascular Health Study. Journal of Clinical Endocrinology and Metabolism 102 4541-4547. (https://doi.org/10.1210/jc.2017-01273)

Arafat AM, Weickert MO, Frystyk J, Spranger J, Schöfl C, Möhlig M \& Pfeiffer AF 2009 The role of insulin-like growth factor (IGF) binding protein-2 in the insulin-mediated decrease in IGF-I bioactivity. Journal of Clinical Endocrinology and Metabolism 94 5093-5101. (https://doi.org/10.1210/jc.2009-0875)

Argente J, Caballo N, Barrios V, Muñoz MT, Pozo J, Chowen JA, Morandé G \& Hernández M 1997 Multiple endocrine abnormalities of the growth hormone and insulin-like growth factor axis in patients with anorexia nervosa: effect of short- and long-term weight recuperation. Journal of Clinical Endocrinology and Metabolism $\mathbf{8 2}$ 2084-2092.

Arnetz L, Dorkhan M, Alvarsson M, Brismar K \& Ekberg NR 2014 Gender differences in non-glycemic responses to improved insulin sensitivity by pioglitazone treatment in patients with type 2 diabetes. Acta Diabetologica 51 185-192. (https://doi.org/10.1007/ s00592-013-0457-y) 
Awede B, Thissen J, Gailly P \& Lebacq J 1999 Regulation of IGF-I, IGFBP4 and IGFBP5 gene expression by loading in mouse skeletal muscle. FEBS Letters 461 263-267. (https://doi.org/10.1016/S00145793(99)01469-6)

Awede BL, Thissen JP \& Lebacq J 2002 Role of IGF-I and IGFBPs in the changes of mass and phenotype induced in rat soleus muscle by clenbuterol. American Journal of Physiology-Endocrinology and Metabolism 282 E31-E37. (https://doi.org/10.1152/ ajpendo.2002.282.1.E31)

Bach LA, Dean R, Youssef S \& Cooper ME 2000 Aminoguanidine ameliorates changes in the IGF system in experimental diabetic nephropathy. Nephrology Dialysis Transplantation 15 347-354. (https://doi.org/10.1093/ndt/15.3.347)

Bae JH, Song DK \& Im SS 2013 Regulation of IGFBP1 in metabolic diseases. Journal of Lifestyle Medicine 3 73-79

Bagi CM, Brommage R, Deleon L, Adams S, Rosen D \& Sommer A 1994 Benefit of systemically administered rhIGF-I and rhIGF-I/IGFBP3 on cancellous bone in ovariectomized rats. Journal of Bone and Mineral Research 9 1301-1312. (https://doi.org/10.1002/jbmr.5650090820)

Bajoria R, Sooranna SR, Ward S \& Chatterjee R 2006 Elevated IGFBP1 cause high bone turnover in growth-restricted monochorionic twins with discordant birth weight. Bone 38 929-934. (https://doi. org/10.1016/j.bone.2005.11.003)

Bamman MM, Shipp JR, Jiang J, Gower BA, Hunter GR, Goodman A, McLafferty CL Jr \& Urban RJ 2001 Mechanical load increases muscle IGF-I and androgen receptor mRNA concentrations in humans. American Journal of Physiology-Endocrinology and Metabolism 280 E383-E390. (https://doi.org/10.1152/ajpendo.2001.280.3.E383)

Bauss F, Lang K, Dony C \& Kling L 2001 The complex of recombinant human insulin-like growth factor-I (rhIGF-I) and its binding protein-5 (IGFBP5) induces local bone formation in murine calvariae and in rat cortical bone after local or systemic administration. Growth Hormone and IGF Research 11 1-9. (https://doi.org/10.1054/ ghir.2000.0181)

Baxter RC 1994 Insulin-like growth factor binding proteins in the human circulation: a review. Hormone Research 42 140-144. (https:// doi.org/10.1159/000184186)

Bayol S, Loughna PT \& Brownson C 2000 Phenotypic expression of IGF binding protein transcripts in muscle, in vitro and in vivo. Biochemical and Biophysical Research Communications 273 282-286. (https://doi.org/10.1006/bbrc.2000.2667)

Bayol S, Jones D, Goldspink G \& Stickland NC 2004 The influence of undernutrition during gestation on skeletal muscle cellularity and on the expression of genes that control muscle growth. British Journal of Nutrition 91 331-339. (https://doi.org/10.1079/ BJN20031070)

Bereket A, Lang CH, Blethen SL \& Wilson TA 1995a Insulin-like growth factor-binding protein-2 and insulin: studies in children with type 1 diabetes mellitus and maturity-onset diabetes of the young. Journal of Clinical Endocrinology and Metabolism 80 3647-3652. (https://doi. org/10.1210/jcem.80.12.8530614)

Bereket A, Lang CH, Blethen SL, Gelato MC, Fan J, Frost RA \& Wilson TA $1995 b$ Effect of insulin on the insulin-like growth factor system in children with new-onset insulin-dependent diabetes mellitus. Journal of Clinical Endocrinology and Metabolism 80 1312-1317.

Berg U, Enqvist JK, Mattsson CM, Carlsson-Skwirut C, Sundberg CJ, Ekblom B \& Bang P 2008 Lack of sex differences in the IGF-IGFBP response to ultra-endurance exercise. Scandinavian Journal of Medicine and Science in Sports 18 706-714. (https://doi. org/10.1111/j.1600-0838.2007.00758.x)

Bodell PW, Kodesh E, Haddad F, Zaldivar FP, Cooper DM \& Adams GR 2009 Skeletal muscle growth in young rats is inhibited by chronic exposure to IL-6 but preserved by concurrent voluntary endurance exercise. Journal of Applied Physiology 106 443-453. (https://doi. org/10.1152/japplphysiol.90831.2008)
Boney CM, Moats-Staats BM, Stiles AD \& D'Ercole AJ 1994 Expression of insulin-like growth factor-I (IGF-I) and IGF-binding proteins during adipogenesis. Endocrinology 135 1863-1868. (https://doi.org/10.1210/ endo.135.5.7525256)

Boonen S, Mohan S, Dequeker J, Aerssens J, Vanderschueren D, Verbeke G, Broos P, Bouillon R \& Baylink DJ 1999 Down-regulation of the serum stimulatory components of the insulin-like growth factor (IGF) system (IGF-I, IGF-II, IGF binding protein [BP]-3, and IGFBP5) in age-related (type II) femoral neck osteoporosis. Journal of Bone and Mineral Research 14 2150-2158. (https://doi.org/10.1359/ jbmr.1999.14.12.2150)

Boonen S, Rosen C, Bouillon R, Sommer A, McKay M, Rosen D, Adams S, Broos P, Lenaerts J, Raus J, et al. 2002 Musculoskeletal effects of the recombinant human IGF-I/IGF binding protein-3 complex in osteoporotic patients with proximal femoral fracture: a double-blind, placebo-controlled pilot study. Journal of Clinical Endocrinology and Metabolism 87 1593-1599. (https://doi. org/10.1210/jcem.87.4.8426)

Boquist S, Ruotolo G, Skoglund-Andersson C, Tang R, Björkegren J, Bond MG, de Faire U, Brismar K \& Hamsten A 2008 Correlation of serum IGF-I and IGFBP1 and -3 to cardiovascular risk indicators and early carotid atherosclerosis in healthy middle-aged men. Clinical Endocrinology 68 51-58. (https://doi. org/10.1111/j.1365-2265.2007.02998.x)

Borai A, Livingstone C, Ghayour-Mobarhan M, Abuosa A, Shafi S, Mehta S, Heidari A, Emadzadeh A, Wark G \& Ferns G 2010 Serum insulin-like growth factor binding protein-1 (IGFBP1) phosphorylation status in subjects with and without ischaemic heart disease. Atherosclerosis 208 593-598. (https://doi.org/10.1016/j. atherosclerosis.2009.08.010)

Brevetti G, Colao A, Schiano V, Pivonello R, Laurenzano E, Di Somma C, Lombardi G \& Chiariello M 2008 IGF system and peripheral arterial disease: relationship with disease severity and inflammatory status of the affected limb. Clinical Endocrinology 69 894-900. (https://doi. org/10.1111/j.1365-2265.2008.03269.x)

Burley SD, Whittingham-Dowd J, Allen J, Grosset JF \& OnambelePearson GL 2016 The differential hormonal milieu of morning versus evening may have an impact on muscle hypertrophic potential. PLOS ONE 11 e0161500. (https://doi.org/10.1371/journal. pone.0161500)

Busby WH, Snyder DK \& Clemmons DR 1988 Radioimmunoassay of a 26,000-dalton plasma insulin-like growth factor-binding protein: control by nutritional variables. Journal of Clinical Endocrinology and Metabolism 67 1225-1230. (https://doi.org/10.1210/jcem-67-61225)

Campbell PG \& Andress DL 1997 Insulin-like growth factor (IGF)binding protein-5-(201-218) region regulates hydroxyapatite and IGF-I binding. American Journal of Physiology 273 E1005-E1013.

Carter S, Li Z, Lemieux I, Alméras N, Tremblay A, Bergeron J, Poirier P, Deshaies Y, Després JP \& Picard F 2014 Circulating IGFBP2 levels are incrementally linked to correlates of the metabolic syndrome and independently associated with VLDL triglycerides. Atherosclerosis 237 645-651. (https://doi.org/10.1016/j. atherosclerosis.2014.09.022)

Ceda GP, Dall'Aglio E, Magnacavallo A, Vargas N, Fontana V, Maggio M, Valenti G, Lee PD, Hintz RL \& Hoffman AR 1998 The insulin-like growth factor axis and plasma lipid levels in the elderly. Journal of Clinical Endocrinology and Metabolism 83 499-502.

Chan SS, Schedlich LJ, Twigg SM \& Baxter RC 2012 Inhibition of adipocyte differentiation by insulin-like growth factor-binding protein-3. Endocrinology 153 4799-4807. (https://doi.org/10.1210/ en.2011-1444)

Chen Y \& Arnqvist HJ 1994 Differential regulation of insulin-like growth factor binding protein-2 and -4 mRNA in muscle tissues and liver by diabetes or fasting. Journal of Endocrinology 143 235-242. (https://doi.org/10.1677/joe.0.1430235) 
Claudio M, Benjamim F, Riccardo B, Massimiliano C, Francesco B \& Luciano C 2010 Adipocytes IGFBP2 expression in prepubertal obese children. Obesity 18 2055-2057. (https://doi.org/10.1038/oby.2010.7)

Clemmons DR 2016 Role of IGF binding proteins in regulating metabolism. Trends in Endocrinology and Metabolism 27 375-391. (https://doi.org/10.1016/j.tem.2016.03.019)

Clemmons DR, Snyder DK \& Busby WH Jr 1991 Variables controlling the secretion of insulin-like growth factor binding protein-2 in normal human subjects. Journal of Clinical Endocrinology and Metabolism 73 727-733. (https://doi.org/10.1210/jcem-73-4-727)

Clemmons DR, Moses AC, McKay MJ, Sommer A, Rosen DM \& Ruckle J 2000 The combination of insulin-like growth factor I and insulinlike growth factor-binding protein-3 reduces insulin requirements in insulin-dependent type 1 diabetes: evidence for in vivo biological activity. Journal of Clinical Endocrinology and Metabolism $\mathbf{8 5}$ 1518-1524.

Clemmons DR, Sleevi M \& Busby WH Jr 2005 Recombinant, nonglycosylated human insulin-like growth factor-binding protein-3 (IGFBP3) is degraded preferentially after administration to type II diabetics, resulting in increased endogenous glycosylated IGFBP3. Journal of Clinical Endocrinology and Metabolism 90 6561-6568. (https://doi.org/10.1210/jc.2005-1389)

Clifton KB \& Conover CA 2001 Pregnancy-associated plasma protein-A modulates the anabolic effects of parathyroid hormone in mouse bone. Endocrinology 142 2641-2648. (https://doi.org/10.1210/ endo.142.6.8192)

Colao A, Spiezia S, Di Somma C, Pivonello R, Marzullo P, Rota F, Musella T, Auriemma RS, De Martino MC \& Lombardi G 2005 Circulating insulin-like growth factor-1 and insulin-like growth factor binding protein-3 are associated with early carotid atherosclerosis. Journal of Endocrinological Investigation 28 440-448. (https://doi.org/10.1007/BF03347225)

Conover CA \& Khosla S 2003 Role of extracellular matrix in insulin-like growth factor (IGF) binding protein-2 regulation of IGF-II action in normal human osteoblasts. Growth Hormone and IGF Research 13 328-335. (https://doi.org/10.1016/S1096-6374(03)00092-3)

Conover CA, Durham SK, Zapf J, Masiarz FR \& Kiefer MC 1995 Cleavage analysis of insulin-like growth factor (IGF)-dependent IGF-binding protein-4 proteolysis and expression of protease-resistant IGFbinding protein-4 mutants. Journal of Biological Chemistry 270 4395-4400. (https://doi.org/10.1074/jbc.270.9.4395)

Conover CA, Johnstone EW, Turner RT, Evans GL, John Ballard FJ, Doran PM \& Khosla S 2002 Subcutaneous administration of insulinlike growth factor (IGF)-II/IGF binding protein-2 complex stimulates bone formation and prevents loss of bone mineral density in a rat model of disuse osteoporosis. Growth Hormone and IGF Research 12 178-183. (https://doi.org/10.1016/S1096-6374(02)00044-8)

Conover CA, Mason MA, Bale LK, Harrington SC, Nyegaard M, Oxvig C \& Overgaard MT 2010 Transgenic overexpression of pregnancyassociated plasma protein-A in murine arterial smooth muscle accelerates atherosclerotic lesion development. American Journal of Physiology-Heart and Circulatory Physiology 299 H284-H291. (https:// doi.org/10.1152/ajpheart.00904.2009)

Contois LW, Nugent DP, Caron JM, Cretu A, Tweedie E, Akalu A, Liebes L, Friesel R, Rosen C, Vary C, et al. 2012 Insulin-like growth factor binding protein- 4 differentially inhibits growth factor-induced angiogenesis. Journal of Biological Chemistry 287 1779-1789. (https:// doi.org/10.1074/jbc.M111.267732)

Cooney RN, Maish GO 3rd, Gilpin T, Shumate ML, Lang CH \& Vary TC 1999 Mechanism of IL-1 induced inhibition of protein synthesis in skeletal muscle. Shock 11 235-241. (https://doi. org/10.1097/00024382-199904000-00002)

Coverley JA, Martin JL \& Baxter RC 2000 The effect of phosphorylation by casein kinase 2 on the activity of insulin-like growth factorbinding protein-3. Endocrinology 141 564-570. (https://doi. org/10.1210/endo.141.2.7306)
Crossey PA, Jones JS \& Miell JP 2000 Dysregulation of the insulin/IGF binding protein-1 axis in transgenic mice is associated with hyperinsulinemia and glucose intolerance. Diabetes 49 457-465. (https://doi.org/10.2337/diabetes.49.3.457)

Crown AL, He XL, Holly JM, Lightman SL \& Stewart CE 2000 Characterisation of the IGF system in a primary adult human skeletal muscle cell model, and comparison of the effects of insulin and IGF-I on protein metabolism. Journal of Endocrinology 167 403-415. (https://doi.org/10.1677/joe.0.1670403)

Dahlfors G \& Arnqvist HJ 2000 Vascular endothelial growth factor and transforming growth factor-beta1 regulate the expression of insulinlike growth factor-binding protein-3, -4 , and -5 in large vessel endothelial cells. Endocrinology 141 2062-2067. (https://doi. org/10.1210/endo.141.6.7481)

Dai W, Kamei H, Zhao Y, Ding J, Du Z \& Duan C 2009 Duplicated zebrafish insulin-like growth factor binding protein-5 genes with split functional domains: evidence for evolutionarily conserved IGF binding, nuclear localization, and transactivation activity. FASEB Journal 23 2616-2626. (https://doi.org/10.1096/fj.08-114124)

Damon SE, Haugk KL, Birnbaum RS \& Quinn LS 1998 Retrovirally mediated overexpression of insulin-like growth factor binding protein 4: evidence that insulin-like growth factor is required for skeletal muscle differentiation. Journal of Cellular Physiology 175 109-120. (https://doi.org/10.1002/(SICI)10974652(199804)175:1<109::AID-JCP12>3.0.CO;2-6)

de Kort SW, van Doorn J, van de Sande AG, Leunissen RW \& HokkenKoelega AC 2010 Serum insulin-like growth factor-binding protein-2 levels and metabolic and cardiovascular risk factors in young adults and children born small for gestational age. Journal of Clinical Endocrinology and Metabolism 95 864-871. (https://doi.org/10.1210/ jc.2009-1508)

de Silva HC, Firth SM, Twigg SM \& Baxter RC 2009 Interaction between IGF binding protein-3 and TGF $\beta$ in the regulation of adipocyte differentiation. American Journal of Physiology-Endocrinology and Metabolism 296 E654-E663. (https://doi.org/10.1152/ ajpendo.90846.2008)

DeMambro VE, Clemmons DR, Horton LG, Bouxsein ML, Wood TL, Beamer WG, Canalis E \& Rosen CJ 2008 Gender-specific changes in bone turnover and skeletal architecture in IGFBP2-null mice. Endocrinology 149 2051-2061. (https://doi.org/10.1210/en.2007-1068)

DeMambro VE, Le PT, Guntur AR, Maridas DE, Canalis E, Nagano K, Baron R, Clemmons DR \& Rosen CJ 2015 Igfbp2 deletion in ovariectomized mice enhances energy expenditure but accelerates bone loss. Endocrinology 156 4129-4140. (https://doi.org/10.1210/ en.2014-1452)

Devlin RD, Du Z, Buccilli V, Jorgetti V \& Canalis E 2002 Transgenic mice overexpressing insulin-like growth factor binding protein-5 display transiently decreased osteoblastic function and osteopenia. Endocrinology 143 3955-3962. (https://doi.org/10.1210/en.2002220129)

DiGirolamo DJ, Mukherjee A, Fulzele K, Gan Y, Cao X, Frank SJ \& Clemens TL 2007 Mode of growth hormone action in osteoblasts. Journal of Biological Chemistry 282 31666-31674. (https://doi. org/10.1074/jbc.M705219200)

Drogan D, Schulze MB, Boeing H \& Pischon T 2016 Insulin-like growth factor 1 and insulin-like growth factor-binding protein 3 in relation to the risk of type 2 diabetes mellitus: results from the EPIC-Potsdam Study. American Journal of Epidemiology 183 553-560. (https://doi. org/10.1093/aje/kwv188)

Ebinger M, Ipsen N, Leonards CO, Empl L, Hanne L, Liman T, Mai K, Strasburger CJ, Spranger J \& Endres M 2015 Circulating insulin-like growth factor binding protein-3 predicts one-year outcome after ischemic stroke. Experimental and Clinical Endocrinology and Diabetes 123 461-465. (https://doi.org/10.1055/s-0035-1554632)

Eggert ML, Wallaschofski H, Grotevendt A, Nauck M, Völzke H, Samietz S \& Friedrich N 2014 Cross-sectional and longitudinal 
relation of IGF1 and IGF-binding protein 3 with lipid metabolism. European Journal of Endocrinology 171 9-19. (https://doi.org/10.1530/ EJE-13-1017)

Ernst M \& Rodan GA 1990 Increased activity of insulin-like growth factor (IGF) in osteoblastic cells in the presence of growth hormone (GH): positive correlation with the presence of the GH-induced IGFbinding protein BP-3. Endocrinology 127 807-814. (https://doi. org/10.1210/endo-127-2-807)

Ernst CW, McFarland DC \& White ME 1996 Expression of insulin-like growth factor II (IGF-II), IGF binding protein-2 and myogenin during differentiation of myogenic satellite cells derived from the turkey. Differentiation 61 25-33. (https://doi. org/10.1046/j.1432-0436.1996.6110025.x)

Ewton DZ \& Florini JR 1995 IGF binding proteins-4, -5 and -6 may play specialized roles during L6 myoblast proliferation and differentiation. Journal of Endocrinology 144 539-553. (https://doi. org/10.1677/joe.0.1440539)

Ewton DZ, Coolican SA, Mohan S, Chernausek SD \& Florini JR 1998 Modulation of insulin-like growth factor actions in L6A1 myoblasts by insulin-like growth factor binding protein (IGFBP)-4 and IGFBP5: a dual role for IGFBP5. Journal of Cellular Physiology 177 47-57. (https://doi.org/10.1002/(SICI)1097-4652(199810)177:1<47::AIDJCP5>3.0.CO;2-E)

Eyster KM, Appt S, Chalpe A, Mark-Kappeler CJ, Register TC \& Clarkson TB 2014 Effects of estradiol on transcriptional profiles in atherosclerotic iliac arteries in ovariectomized cynomolgus macaques. Menopause 21 143-152. (https://doi.org/10.1097/ GME.0b013e31829367c0)

Fan J, Char D, Bagby GJ, Gelato MC \& Lang CH 1995 Regulation of insulin-like growth factor-I (IGF-I) and IGF-binding proteins by tumor necrosis factor. American Journal of Physiology 269 R1204-R1212.

Fanayan S, Firth SM \& Baxter RC 2002 Signaling through the Smad pathway by insulin-like growth factor-binding protein-3 in breast cancer cells. Relationship to transforming growth factor-beta 1 signaling. Journal of Biological Chemistry 277 7255-7261. (https://doi. org/10.1074/jbc.M108038200)

Fischer F, Schulte H, Mohan S, Tataru MC, Köhler E, Assmann G \& von Eckardstein A 2004 Associations of insulin-like growth factors, insulin-like growth factor binding proteins and acid-labile subunit with coronary heart disease. Clinical Endocrinology 61 595-602. (https://doi.org/10.1111/j.1365-2265.2004.02136.x)

Fontana L, Villareal DT, Das SK, Smith SR, Meydani SN, Pittas AG, Klein S, Bhapkar M, Rochon J, Ravussin E, et al. 2016 Effects of 2-year calorie restriction on circulating levels of IGF-1, IGF-binding proteins and cortisol in nonobese men and women: a randomized clinical trial. Aging Cell 15 22-27. (https://doi.org/10.1111/ acel.12400)

Foulstone EJ, Savage PB, Crown AL, Holly JM \& Stewart CE 2003 Role of insulin-like growth factor binding protein-3 (IGFBP3) in the differentiation of primary human adult skeletal myoblasts. Journal of Cellular Physiology 195 70-79. (https://doi.org/10.1002/jcp.10227)

Friedrich N, Haring R, Nauck M, Lüdemann J, Rosskopf D, Spilcke-Liss E, Felix SB, Dörr M, Brabant G, Völzke H, et al. 2009 Mortality and serum insulin-like growth factor (IGF)-I and IGF binding protein 3 concentrations. Journal of Clinical Endocrinology and Metabolism 94 1732-1739. (https://doi.org/10.1210/jc.2008-2138)

Frost RA \& Lang CH 1999 Differential effects of insulin-like growth factor I (IGF-I) and IGF-binding protein-1 on protein metabolism in human skeletal muscle cells. Endocrinology 140 3962-3970. (https:// doi.org/10.1210/endo.140.9.6998)

Fuentes EN, Einarsdottir IE, Paredes R, Hidalgo C, Valdes JA, Björnsson BT \& Molina A 2015 The TORC1/P70S6K and TORC1/4EBP1 signaling pathways have a stronger contribution on skeletal muscle growth than MAPK/ERK in an early vertebrate: differential involvement of the IGF system and atrogenes. General and Comparative Endocrinology 210 96-106. (https://doi.org/10.1016/j. ygcen.2014.10.012)

Gabbitas B \& Canalis E 1996 Cortisol enhances the transcription of insulin-like growth factor-binding protein-6 in cultured osteoblasts. Endocrinology 137 1687-1692. (https://doi.org/10.1210/ endo.137.5.8612502)

Gabbitas B \& Canalis E 1998 Insulin-like growth factors sustain insulinlike growth factor-binding protein-5 expression in osteoblasts. American Journal of Physiology 275 E222-E228.

Garfinkel BP, Arad S, Le PT, Bustin M, Rosen CJ, Gabet Y \& Orly J 2015 Proportionate dwarfism in mice lacking heterochromatin protein 1 binding protein 3 (HP1BP3) is associated with alterations in the endocrine IGF-1 pathway. Endocrinology 156 4558-4570. (https://doi. org/10.1210/en.2015-1668)

Gautsch TA, Kandl SM, Donovan SM \& Layman DK 1998 Response of the IGF-I system to prolonged undernutrition and its involvement in somatic and skeletal muscle growth retardation in rats. Growth, Development, and Aging 62 13-25.

Gealekman O, Gurav K, Chouinard M, Straubhaar J, Thompson M, Malkani S, Hartigan C \& Corvera S 2014 Control of adipose tissue expandability in response to high fat diet by the insulin-like growth factor-binding protein-4. Journal of Biological Chemistry $\mathbf{2 8 9}$ 18327-18338. (https://doi.org/10.1074/jbc.M113.545798)

Giannini S, Cresci B, Pala L, Ciucci A, Franchini A, Manuelli C, FujitaYamaguchi Y, Cappugi P, Zonefrati R \& Rotella CM 2001 IGFBPs modulate IGF-I- and high glucose-controlled growth of human retinal endothelial cells. Journal of Endocrinology 171 273-284. (https://doi.org/10.1677/joe.0.1710273)

Gibson JM, Westwood M, Young RJ \& White A 1996 Reduced insulinlike growth factor binding protein-1 (IGFBP1) levels correlate with increased cardiovascular risk in non-insulin dependent diabetes mellitus (NIDDM). Journal of Clinical Endocrinology and Metabolism $\mathbf{8 1}$ 860-863.

Gillberg P, Olofsson H, Mallmin H, Blum WF, Ljunghall S \& Nilsson AG 2002 Bone mineral density in femoral neck is positively correlated to circulating insulin-like growth factor (IGF)-I and IGF-binding protein (IGFBP)-3 in Swedish men. Calcified Tissue International 70 22-29. (https://doi.org/10.1007/s002230020048)

Gleason CE, Ning Y, Cominski TP, Gupta R, Kaestner KH, Pintar JE \& Birnbaum MJ 2010 Role of insulin-like growth factor-binding protein 5 (IGFBP5) in organismal and pancreatic beta-cell growth. Molecular Endocrinology 24 178-192. (https://doi.org/10.1210/ me.2009-0167)

Gokulakrishnan K, Velmurugan K, Ganesan S \& Mohan V 2012 Circulating levels of insulin-like growth factor binding protein-1 in relation to insulin resistance, type 2 diabetes mellitus, and metabolic syndrome (Chennai Urban Rural Epidemiology Study 118). Metabolism 61 43-46. (https://doi.org/10.1016/j. metabol.2011.05.014)

Grinspoon S, Miller K, Herzog D, Clemmons D \& Klibanski A 2003 Effects of recombinant human insulin-like growth factor (IGF)-I and estrogen administration on IGF-I, IGF binding protein (IGFBP)-2, and IGFBP3 in anorexia nervosa: a randomized-controlled study. Journal of Clinical Endocrinology and Metabolism 88 1142-1149. (https://doi.org/10.1210/jc.2002-021402)

Grzelkowska-Kowalczyk K, Wieteska-Skrzeczyńska W, Grabiec K \& Tokarska J 2013 High glucose-mediated alterations of mechanisms important in myogenesis of mouse $\mathrm{C} 2 \mathrm{C} 12$ myoblasts. Cell Biology International 37 29-35. (https://doi.org/10.1002/cbin.10004)

Gu T, Gu HF, Hilding A, Sjöholm LK, Ostenson CG \& Ekström TJ 2013 Brismar increased DNA methylation levels of the insulin-like growth factor binding protein 1 gene are associated with type 2 diabetes in Swedish men. Clinical Epigenetics 5 21-27. (https://doi. org/10.1186/1868-7083-5-21)

Gu T, Falhammar H, Gu HF\& Brismar K 2014 Epigenetic analyses of the insulin-like growth factor binding protein 1 gene in type 1 diabetes 
and diabetic nephropathy. Clinical Epigenetics 6 10. (https://doi. org/10.1186/1868-7083-6-30)

Guerra-Menéndez L, Sádaba MC, Puche JE, Lavandera JL, de Castro LF, de Gortázar AR \& Castilla-Cortázar I 2013 IGF-I increases markers of osteoblastic activity and reduces bone resorption via osteoprotegerin and RANK-ligand. Journal of Translational Medicine 11 271-279.

Ha YM, Nam JO \& Kang YJ 2015 Pitavastatin regulates Ang II induced proliferation and migration via IGFBP5 in VSMC. Korean Journal of Physiology and Pharmacology 19 499-506. (https://doi.org/10.4196/ kjpp.2015.19.6.499)

Halim SA, Neely ML, Pieper KS, Shah SH, Kraus WE, Hauser ER, Califf RM, Granger CB \& Newby LK 2015 Simultaneous consideration of multiple candidate protein biomarkers for longterm risk for cardiovascular events. Circulation: Cardiovascular Genetic 8 168-177. (https://doi.org/10.1161/CIRCGENETICS.113.000490)

Ham KD, Oegema TR, Loeser RF \& Carlson CS 2004 Effects of long-term estrogen replacement therapy on articular cartilage IGFBP2, IGFBP3, collagen and proteoglycan levels in ovariectomized cynomolgus monkeys. Osteoarthritis Cartilage 12 160-168. (https://doi. org/10.1016/j.joca.2003.08.002)

Hamidouche Z, Fromigué O, Ringe J, Häupl T \& Marie PJ 2010 Crosstalks between integrin alpha 5 and IGF2/IGFBP2 signalling trigger human bone marrow-derived mesenchymal stromal osteogenic differentiation. BMC Cell Biology 11 44-49. (https://doi org/10.1186/1471-2121-11-44)

Han HJ, Kang CW \& Park SH 2006 Tissue-specific regulation of insulinlike growth factors and insulin-like growth factor binding proteins in male diabetic rats in vivo and in vitro. Clinical and Experimental Pharmacology and Physiology 33 1172-1179. (https://doi. org/10.1111/j.1440-1681.2006.04495.x)

Han N, Zhang F, Li G, Zhang X, Lin X, Yang H, Wang L, Cao Y, Du J \& Fan Z 2017 Local application of IGFBP5 protein enhanced periodontal tissue regeneration via increasing the migration, cell proliferation and osteo/dentinogenic differentiation of mesenchymal stem cells in an inflammatory niche. Stem Cell Research and Therapy 8 210-217. (https://doi.org/10.1186/s13287-017-0663-6)

Harrington SC, Simari RD \& Conover CA 2007 Genetic deletion of pregnancy-associated plasma protein-A is associated with resistance to atherosclerotic lesion development in apolipoprotein E-deficient mice challenged with a high-fat diet. Circulation Research 100 1696-1702. (https://doi.org/10.1161/CIRCRESAHA.106.146183)

Hedbacker K, Birsoy K, Wysocki RW, Asilmaz E, Ahima RS, Farooqi IS \& Friedman JM 2010 Antidiabetic effects of IGFBP2, a leptin-regulated gene. Cell Metabolism 11 11-22. (https://doi.org/10.1016/j. cmet.2009.11.007)

Henning PC, Scofield DE, Rarick KR, Pierce JR, Staab JS, Lieberman HR \& Nindl BC 2013 Effects of acute caloric restriction compared to caloric balance on the temporal response of the IGF-I system. Metabolism 62 179-187. (https://doi.org/10.1016/j.metabol.2012.07.004)

Hirai H, Kanaya R, Maeda M, Qungfang D, Ina K \& Hayashi T 2011 The role of insulin growth factor on atherosclerosis and endothelial function: the effect on hyperlipidemia and aging. Life Sciences $\mathbf{8 8}$ 425-431. (https://doi.org/10.1016/j.lfs.2010.12.021)

Hjortebjerg R, Tarnow L, Jorsal A, Parving HH, Rossing P, Bjerre M \& Frystyk J 2015 IGFBP4 fragments as markers of cardiovascular mortality in type 1 diabetes patients with and without nephropathy. Journal of Clinical Endocrinology and Metabolism 100 3032-3040. (https://doi.org/10.1210/jc.2015-2196)

Hjortebjerg R, Laugesen E, Høyem P, Oxvig C, Stausbøl-Grøn B, Knudsen ST, Kim WY, Poulsen PL, Hansen TK, Bjerre M, et al. 2017 The IGF system in patients with type 2 diabetes: associations with markers of cardiovascular target organ damage. European Journal of Endocrinology 176 521-531. (https://doi.org/10.1530/EJE-16-0940)

Hoeflich A, Wu M, Mohan S, Föll J, Wanke R, Froehlich T, Arnold GJ, Lahm H, Kolb HJ \& Wolf E 1999 Overexpression of insulin-like growth factor-binding protein-2 in transgenic mice reduces postnatal body weight gain. Endocrinology 140 5488-5496. (https://doi. org/10.1210/endo.140.12.7169)

Högler W, Martin DD, Crabtree N, Nightingale P, Tomlinson J, Metherell L, Rosenfeld R, Hwa V, Rose S, Walker J, et al. 2014 IGFALS gene dosage effects on serum IGF-I and glucose metabolism, body composition, bone growth in length and width, and the pharmacokinetics of recombinant human IGF-I administration. Journal of Clinical Endocrinology and Metabolism 99 E703-E712.

James PL, Stewart CE \& Rotwein P 1996 Insulin-like growth factor binding protein-5 modulates muscle differentiation through an insulin-like growth factor-dependent mechanism. Journal of Cell Biology 133 683-693. (https://doi.org/10.1083/jcb.133.3.683)

Jassal SK, von Muhlen D, Barrett-Connor E \& Rosen CJ Serum insulinlike growth factor binding protein-1 levels and bone mineral density in older adults: the Rancho Bernardo Study. Osteoporosis International 200516 1948-1954. (https://doi.org/10.1007/s00198-005-1973-6)

Jehle PM, Jehle DR, Mohan S \& Böhm BO 1998 Serum levels of insulinlike growth factor system components and relationship to bone metabolism in type 1 and type 2 diabetes mellitus patients. Journal of Endocrinology 159 297-306. (https://doi.org/10.1677/ joe.0.1590297)

Jehle PM, Schulten K, Schulz W, Jehle DR, Stracke S, Manfras B, Boehm BO, Baylink DJ \& Mohan S 2003 Serum levels of insulin-like growth factor (IGF)-I and IGF binding protein (IGFBP)- 1 to -6 and their relationship to bone metabolism in osteoporosis patients. European Journal of Internal Medicine 14 32-38. (https://doi. org/10.1016/S0953-6205(02)00183-8)

Jennische E \& Hall CM 2000 Expression and localisation of IGF-binding protein mRNAs in regenerating rat skeletal muscle. APMIS $\mathbf{1 0 8}$ 747-755. (https://doi.org/10.1034/j.1600-0463.2000.d01-24.x)

Johansson AG, Baylink DJ, af Ekenstam E, Lindh E, Mohan S \& Ljunghall S 1994 Circulating levels of insulin-like growth factor-I and -II, and IGF-binding protein-3 in inflammation and after parathyroid hormone infusion. Bone Mineral 24 25-31. (https://doi. org/10.1016/S0169-6009(08)80128-6)

Johansson AG, Eriksen EF, Lindh E, Langdahl B, Blum WF, Lindahl A, Ljunggren O \& Ljunghall S 1997 Reduced serum levels of the growth hormone-dependent insulin-like growth factor binding protein and a negative bone balance at the level of individual remodeling units in idiopathic osteoporosis in men. Journal of Clinical Endocrinology and Metabolism 82 2795-2798.

Jones JI \& Clemmons DR 1995 Insulin-like growth factors and their binding proteins: biological actions. Endocrine Reviews 16 3-34. (https://doi.org/10.1210/edrv-16-1-3)

Jones JI, D'Ercole AJ, Camacho-Hubner C \& Clemmons DR 1991 Phosphorylation of insulin-like growth factor (IGF)-binding protein 1 in cell culture and in vivo: effects on affinity for IGF-I. PNAS $\mathbf{8 8}$ 7481-7485. (https://doi.org/10.1073/pnas.88.17.7481)

Jones JI, Gockerman A, Busby WH Jr, Wright G \& Clemmons DR 1993a Insulin-like growth factor binding protein 1 stimulates cell migration and binds to the alpha 5 beta 1 integrin by means of its Arg-Gly-Asp sequence. PNAS 90 10553-10557. (https://doi.org/10.1073/ pnas.90.22.10553)

Jones JI, Gockerman A, Busby WH Jr, Camacho-Hubner C \& Clemmons DR 1993b Extracellular matrix contains insulin-like growth factor binding protein-5: potentiation of the effects of IGF-I. Journal of Cell Biology 121 679-687. (https://doi.org/10.1083/ jcb.121.3.679)

Kadaba R, Barron D, Lewitt MS \& Murphy LJ 1995 Growth retardation and hyperglycemia in insulin-like growth factor binding protein-1 transgenic mice Endocrinology 136 4029-4034. (https://doi. org/10.1210/endo.136.9.7544274)

Kallio P, Tolppanen AM, Kolehmainen M, Poutanen K, Lindström J, Tuomilehto J, Kuulasmaa T, Kuusisto J, Pulkkinen L \& Uusitupa M 2009 Association of sequence variations in the gene encoding insulin-like growth factor binding protein 5 with adiponectin. 
International Journal of Obesity 33 80-88. (https://doi.org/10.1038/ ijo.2008.196)

Kammel A, Saussenthaler S, Jähnert M, Jonas W, Stirm L, Hoeflich A, Staiger H, Fritsche A, Häring HU, Joost HG, et al. 2016 Early hypermethylation of hepatic Igfbp 2 results in its reduced expression preceding fatty liver in mice. Human Molecular Genetics 25 2588-2599.

Kanatani M, Sugimoto T, Nishiyama K \& Chihara K 2000 Stimulatory effect of insulin-like growth factor binding protein-5 on mouse osteoclast formation and osteoclastic bone-resorbing activity. Journal of Bone and Mineral Research 15 902-910. (https://doi.org/10.1359/ jbmr.2000.15.5.902)

Kang HS, Kim MY, Kim SJ, Lee JH, Kim YD, Seo YK, Bae JH, Oh GT, Song DK, Ahn YH, et al. 2015 Regulation of IGFBP2 expression during fasting. Biochemical Journal 467 453-460. (https://doi. org/10.1042/BJ20141248)

Kang HS, Cho HC, Lee JH, Oh GT, Koo SH, Park BH, Lee IK, Choi HS, Song DK \& Im SS 2016 Metformin stimulates IGFBP2 gene expression through PPAR alpha in diabetic states. Scientific Reports 6 23665. (https://doi.org/10.1038/srep23665)

Kaplan RC, McGinn AP, Pollak MN, Kuller LH, Strickler HD, Rohan TE, Cappola AR, Xue X \& Psaty BM 2007 Association of total insulin-like growth factor-I, insulin-like growth factor binding protein-1 (IGFBP1), and IGFBP3 levels with incident coronary events and ischemic stroke. Journal of Clinical Endocrinology and Metabolism 92 1319-1325. (https://doi.org/10.1210/jc.2006-1631)

Kaplan RC, Strizich G, Aneke-Nash C, Dominguez-Islas C, Bužková P, Strickler H, Rohan T, Pollak M, Kuller L, Kizer JR, et al. 2017 Insulinlike growth factor binding protein-1 and ghrelin predict health outcomes among older adults: Cardiovascular Health Study Cohort. Journal of Clinical Endocrinology and Metabolism 102 267-278.

Karasik D1, Rosen CJ, Hannan MT, Broe KE, Dawson-Hughes B, Gagnon DR, Wilson PW, Visser M, Langlois JA, Mohan S, et al. 2002 Insulin-like growth factor binding proteins 4 and 5 and bone mineral density in elderly men and women. Calcified Tissue International 71 323-328. (https://doi.org/10.1007/s00223-0021002-0)

Kassem M, Okazaki R, De León D, Harris SA, Robinson JA, Spelsberg TC, Conover CA \& Riggs BL 1996 Potential mechanism of estrogenmediated decrease in bone formation: estrogen increases production of inhibitory insulin-like growth factor-binding protein-4. Proceedings of the Association of American Physicians 108 155-164.

Katz LE, Gralewski KA, Abrams P, Brar PC, Gallagher PR, Lipman TH, Brooks LJ \& Koren D 2016 Insulin-like growth factor-I and insulinlike growth factor binding protein-1 are related to cardiovascular disease biomarkers in obese adolescents. Pediatric Diabetes 17 77-86. (https://doi.org/10.1111/pedi.12242)

Kawachi S, Takeda N, Sasaki A, Kokubo Y, Takami K, Sarui H, Hayashi M, Yamakita N \& Yasuda K 2005 Circulating insulin-like growth factor-I levels are correlated with the atherosclerotic profile in healthy subjects independently of age. Arteriosclerosis, Thrombosis, and Vascular Biology 25 617-621. (https://doi.org/10.1161/01. ATV.0000154486.03017.35)

Kawai M, Breggia AC, DeMambro VE, Shen X, Canalis E, Bouxsein ML, Beamer WG, Clemmons DR \& Rosen CJ 2011 The heparin-binding domain of IGFBP2 has insulin-like growth factor bindingindependent biologic activity in the growing skeleton. Journal of Biological Chemistry 286 14670-14680. (https://doi.org/10.1074/jbc. M110.193334)

Kennedy OD, Sun H, Wu Y, Courtland HW, Williams GA, Cardoso L, Basta-Pljakic J, Schaffler MB \& Yakar S 2014 Skeletal response of male mice to anabolic hormone therapy in the absence of the Igfals gene. Endocrinology 155 987-999. (https://doi.org/10.1210/en.2013-1819)

Kiepe D, Ulinski T, Powell DR, Durham SK, Mehls O \& Tönshoff B 2002 Differential effects of insulin-like growth factor binding proteins-1, $-2,-3$, and -6 on cultured growth plate chondrocytes. Kidney
International 62 1591-1600. (https://doi. org/10.1046/j.1523-1755.2002.00603.x)

Kiepe D, Ciarmatori S, Hoeflich A, Wolf E \& Tönshoff B 2005 Insulinlike growth factor (IGF)-I stimulates cell proliferation and induces IGF binding protein (IGFBP)-3 and IGFBP5 gene expression in cultured growth plate chondrocytes via distinct signaling pathways. Endocrinology 146 3096-3104. (https://doi.org/10.1210/en.2005-0324)

Kiepe D, Ciarmatori S, Haarmann A \& Tönshoff B 2006 Differential expression of IGF system components in proliferating vs. differentiating growth plate chondrocytes: the functional role of IGFBP5. American Journal of Physiology-Endocrinology and Metabolism 290 E363-E367. (https://doi.org/10.1152/ajpendo.00363.2005)

Kiepe D, Van Der Pas A, Ciarmatori S, Ständker L, Schütt B, Hoeflich A, Hügel U, Oh J \& Tönshoff B 2015 Defined carboxy-terminal fragments of insulin-like growth factor (IGF) binding protein-2 exert similar mitogenic activity on cultured rat growth plate chondrocytes as IGF-I. Endocrinology 156 4129-4140. (https://doi.org/10.1210/ en.2014-1452)

Kim MS \& Lee DY 2015 Insulin-like growth factor (IGF)-I and IGF binding proteins axis in diabetes mellitus. Annals of Pediatric Endocrinology and Metabolism 20 69-73. (https://doi.org/10.6065/ apem.2015.20.2.69)

Kim JG, Shin CS, Choi YM, Moon SY, Kim SY \& Lee JY 1999 The relationship among circulating insulin-like growth factor components, biochemical markers of bone turnover and bone mineral density in postmenopausal women under the age of 60 Clinical Endocrinology 51 301-307. (https://doi. org/10.1046/j.1365-2265.1999.00769.x)

Kim JH, Yoon SM, Song SU, Park SG, Kim WS, Park IG, Lee J \& Sung JH 2016 Hypoxia suppresses spontaneous mineralization and osteogenic differentiation of mesenchymal stem cells via IGFBP3 up-regulation. International Journal of Molecular Sciences 17 E1389. (https://doi. org/10.3390/ijms17091389)

Ko JM, Park HK, Yang S, Kim EY, Chung SC \& Hwang IT 2012 Association between insulin-like growth factor binding protein-2 levels and cardiovascular risk factors in Korean children. Endocrine Journal 59 335-343. (https://doi.org/10.1507/endocrj.EJ11-0358)

Koh A, Niikura T, Lee SY, Oe K, Koga T, Dogaki Y \& Kurosaka M 2011 Differential gene expression and immunolocalization of insulin-like growth factors and insulin-like growth factor binding proteins between experimental nonunions and standard healing fractures. Journal of Orthopaedic Research 29 1820-1826. (https://doi. org/10.1002/jor.21457)

Kotronen A, Lewitt M, Hall K, Brismar K \& Yki-Järvinen H 2008 Insulinlike growth factor binding protein 1 as a novel specific marker of hepatic insulin sensitivity. Journal of Clinical Endocrinology and Metabolism 93 4867-4872. (https://doi.org/10.1210/jc.2008-1245)

Kveiborg M, Flyvbjerg A, Rattan SI \& Kassem M 2000 Changes in the insulin-like growth factor-system may contribute to in vitro agerelated impaired osteoblast functions. Experimental Gerontology $\mathbf{3 5}$ 1061-1074. (https://doi.org/10.1016/S0531-5565(00)00125-X)

Kveiborg M, Flyvbjerg A \& Kassem M 2002 Synergistic effects of 1,25-Dihydroxyvitamin D3 and TGF-beta1 on the production of insulin-like growth factor binding protein 3 in human bone marrow stromal cell cultures. APMIS 110 410-414. (https://doi. org/10.1034/j.1600-0463.2002.100507.x)

Lam CS, Chen MH, Lacey SM, Yang Q, Sullivan LM, Xanthakis V, Safa R, Smith HM, Peng X, Sawyer DB, et al. 2010 Circulating insulin-like growth factor-1 and its binding protein-3: metabolic and genetic correlates in the community. Arteriosclerosis, Thrombosis, and Vascular Biology 30 1479-1484. (https://doi.org/10.1161/ ATVBAHA.110.203943)

Lang CH, Liu X, Nystrom GJ \& Frost R 2000 Acute response of IGF-I and IGF binding proteins induced by thermal injury. American Journal of Physiology-Endocrinology and Metabolism 278 E1087-E1096. (https:// doi.org/10.1152/ajpendo.2000.278.6.E1087) 
Lang CH, Vary TC \& Frost RA 2003 Acute in vivo elevation of insulinlike growth factor (IGF) binding protein-1 decreases plasma free IGF-I and muscle protein synthesis. Endocrinology 144 3922-3933. (https://doi.org/10.1210/en.2002-0192)

Lang CH, Frost RA, Svanberg E \& Vary TC 2004 IGF-I/IGFBP3 ameliorates alterations in protein synthesis, eIF4E availability, and myostatin in alcohol-fed rats. American Journal of PhysiologyEndocrinology and Metabolism 286 E916-E926. (https://doi. org/10.1152/ajpendo.00554.2003)

Lang CH, Krawiec BJ, Huber D, McCoy JM \& Frost RA 2006 Sepsis and inflammatory insults downregulate IGFBP5, but not IGFBP4, in skeletal muscle via a TNF-dependent mechanism. American Journal of Physiology-Regulatory, Integrative and Comparative Physiology 290 R963-R972. (https://doi.org/10.1152/ajpregu.00684.2005)

Leal SM, Huang SS \& Huang JS 1999 Interactions of high affinity insulin-like growth factor-binding proteins with the type $\mathrm{V}$ transforming growth factor-beta receptor in mink lung epithelial cells. Journal of Biological Chemistry 274 6711-6717. (https://doi. org/10.1074/jbc.274.10.6711)

Lebrasseur NK, Achenbach SJ, Melton LJ 3rd, Amin S \& Khosla S 2012 Skeletal muscle mass is associated with bone geometry and microstructure and serum insulin-like growth factor binding protein-2 levels in adult women and men. Journal of Bone and Mineral Research 27 2159-2169. (https://doi.org/10.1002/ jbmr.1666)

Lee DH, Kim JE \& Kang YJ 2013 Insulin like growth factor binding protein-5 regulates excessive vascular smooth muscle cell proliferation in spontaneously hypertensive rats via ERK $1 / 2$ phosphorylation. Korean Journal of Physiology and Pharmacology 17 157-162. (https://doi.org/10.4196/kjpp.2013.17.2.157)

Leinonen ES, Salonen JT, Salonen RM, Koistinen RA, Leinonen PJ, Sarna SS \& Taskinen MR 2002 Reduced IGFBP1 is associated with thickening of the carotid wall in type 2 diabetes. Diabetes Care $\mathbf{2 5}$ 1807-1812. (https://doi.org/10.2337/diacare.25.10.1807)

Lewis MI, Horvitz GD, Clemmons DR \& Fournier M 2002 Role of IGF-I and IGF-binding proteins within diaphragm muscle in modulating the effects of nandrolone. American Journal of Physiology-Endocrinology and Metabolism 282 E483-E490. (https://doi.org/10.1152/ ajpendo.00191.2001)

Lewitt MS \& Baxter RC 1991 Insulin-like growth factor-binding protein-1: a role in glucose counterregulation? Molecular and Cellular Endocrinology 79 C147-C152. (https://doi.org/10.1016/03037207(91)90086-8)

Lewitt MS, Hilding A, Ostenson CG, Efendic S, Brismar K \& Hall K 2008 Insulin-like growth factor-binding protein-1 in the prediction and development of type 2 diabetes in middle-aged Swedish men. Diabetologia 51 1135-1145. (https://doi.org/10.1007/s00125-0081016-x)

Lewitt MS, Hilding A, Brismar K, Efendic S, Ostenson CG \& Hall K 2010 IGF-binding protein 1 and abdominal obesity in the development of type 2 diabetes in women. European Journal of Endocrinology 163 233-242. (https://doi.org/10.1530/EJE-10-0301)

Li Z \& Picard F 2010 Modulation of IGFBP2 mRNA expression in white adipose tissue upon aging and obesity. Hormone and Metabolic Research 42 787-791. (https://doi.org/10.1055/s-0030-1262854)

Li Z, Martin J, Poirier P, Caron-Cantin SM, Hould FS, Marceau S, Marceau P \& Picard F 2012 Upregulation of plasma insulin-like growth factor binding protein 2 levels after biliopancreatic diversion in humans. Obesity 20 1469-1473. (https://doi.org/10.1038/ oby.2012.90)

Liu Z, Han T, Fishman S, Butler J, Zimmermann T, Tremblay F, Harbison C, Agrawal N, Kopchick JJ, Schaffler MB, et al. 2017 Ablation of hepatic production of the acid-labile subunit in bovine-GH transgenic mice: effects on organ and skeletal growth. Endocrinology 158 2556-2571. (https://doi.org/10.1210/en.2016-1952)
Lu J, Liu KC, Schulz N, Karampelias C, Charbord J, Hilding A, Rautio L, Bertolino P, Östenson CG, Brismar K, et al. 2016 IGFBP1 increases $\beta$-cell regeneration by promoting $\alpha$ - to $\beta$-cell transdifferentiation. EMBO Journal 35 2026-2044. (https://doi.org/10.15252/ embj.201592903)

Lundin H, Sääf M, Strender LE, Nyren S, Johansson SE \& Salminen H 2016 High serum insulin-like growth factor-binding protein 1 (IGFBP1) is associated with high fracture risk independent of insulinlike growth factor 1 (IGF-I). Calcified Tissue International 99 333-339. (https://doi.org/10.1007/s00223-016-0152-4)

Maggio M, Cattabiani C, Lauretani F, Bandinelli S, De Vita F, Dall'Aglio E, Corsonello A, Lattanzio F, Paolisso G, Ferrucci L, et al. 2013 Insulin-like growth factor-1 bioactivity plays a prosurvival role in older participants. Journals of Gerontology Series: A Biological Sciences and Medical Sciences 68 1342-1350. (https://doi.org/10.1093/ gerona/glt045)

Malpe R, Baylink DJ, Linkhart TA, Wergedal JE \& Mohan S 1997 Insulinlike growth factor (IGF)-I, -II, IGF binding proteins (IGFBP)-3, -4, and -5 levels in the conditioned media of normal human bone cells are skeletal site-dependent. Journal of Bone and Mineral Research 12 423-430. (https://doi.org/10.1359/jbmr.1997.12.3.423)

Maridas DE, DeMambro VE, Le PT, Nagano K, Baron R, Mohan S \& Rosen CJ 2017 IGFBP4 regulates adult skeletal growth in a sexspecific manner. Journal of Endocrinology 233 131-144. (https://doi. org/10.1530/JOE-16-0673)

Martin JL \& Baxter RC 2011 Signalling pathways of insulin-like growth factors (IGFs) and IGF binding protein-3. Growth Factors 6 235-244. (https://doi.org/10.3109/08977194.2011.614237)

Martin RM, Gunnell D, Whitley E, Nicolaides A, Griffin M, Georgiou N, Davey Smith G, Ebrahim S \& Holly JM 2008 Associations of insulinlike growth factor (IGF)-I, IGF-II, IGF binding protein (IGFBP)-2 and IGFBP3 with ultrasound measures of atherosclerosis and plaque stability in an older adult population. Journal of Clinical Endocrinology and Metabolism 93 1331-1338. (https://doi.org/10.1210/jc.20072295)

Martin JL, de Silva HC, Lin MZ, Scott CD \& Baxter RC 2014 Inhibition of insulin-like growth factor-binding protein-3 signaling through sphingosine kinase-1 sensitizes triple-negative breast cancer cells to EGF receptor blockade. Molecular Cancer Therapeutics 13 316-328. (https://doi.org/10.1158/1535-7163.MCT-13-0367)

McCusker RH, Campion DR, Jones WK \& Clemmons DR 1989 The insulin-like growth factor-binding proteins of porcine serum: endocrine and nutritional regulation. Endocrinology 125 501-509. (https://doi.org/10.1210/endo-125-1-501)

Meadows KA, Holly JM \& Stewart CE 2000 Tumor necrosis factor-alphainduced apoptosis is associated with suppression of insulin-like growth factor binding protein-5 secretion in differentiating murine skeletal myoblasts. Journal of Cellular Physiology 183 330-337. (https://doi.org/10.1002/(SICI)1097-4652(200006)183:3<330::AIDJCP5 $>3.0 . \mathrm{CO} ; 2-\mathrm{N}$ )

Messmer-Blust AF, Philbrick MJ, Guo S, Wu J, He P, Guo S \& Li J 2012 RTEF-1 attenuates blood glucose levels by regulating insulin-like growth factor binding protein-1 in the endothelium. Circulation Research 111 991-1001. (https://doi.org/10.1161/ CIRCRESAHA.112.268110)

Mikkelsen JH, Resch ZT, Kalra B, Savjani G, Kumar A, Conover CA \& Oxvig C 2014 Indirect targeting of IGF receptor signaling in vivo by substrate-selective inhibition of PAPP-A proteolytic activity. Oncotarget 5 1014-1025.

Miyakoshi N, Richman C, Qin X, Baylink DJ \& Mohan S 1999 Effects of recombinant insulin-like growth factor-binding protein-4 on bone formation parameters in mice. Endocrinology 140 5719-5728. (https://doi.org/10.1210/endo.140.12.7175)

Miyakoshi N, Richman C, Kasukawa Y, Linkhart TA, Baylink DJ \& Mohan S 2001 Evidence that IGF-binding protein-5 functions as a 
growth factor. Journal of Clinical Investigation 107 73-81. (https://doi. org/10.1172/JCI10459)

Miyakoshi N, Qin X, Kasukawa Y, Richman C, Srivastava AK, Baylink DJ \& Mohan S 2015 Systemic administration of insulin-like growth factor (IGF)-binding protein-4 (IGFBP4) increases bone formation parameters in mice by increasing IGF bioavailability via an IGFBP4 protease-dependent mechanism. Bone 81 413-416. (https://doi. org/10.1016/j.bone.2015.08.015)

Mohamed-Ali V, Pinkney JH, Panahloo A, Cwyfan-Hughes S, Holly JM \& Yudkin JS 1999 Insulin-like growth factor binding protein-1 in NIDDM: relationship with the insulin resistance syndrome Clinical Endocrinology 50 221-228. (https://doi. org/10.1046/j.1365-2265.1999.00647.x)

Mohan S \& Baylink DJ 1997 Serum insulin-like growth factor binding protein (IGFBP)-4 and IGFBP5 levels in aging and age-associated diseases. Endocrine 7 87-91. (https://doi.org/10.1007/BF02778070)

Mohan S, Nakao Y, Honda Y, Landale E, Leser U, Dony C, Lang K \& Baylink DJ 1995 Studies on the mechanisms by which insulin-like growth factor (IGF) binding protein-4 (IGFBP4) and IGFBP5 modulate IGF actions in bone cells. Journal of Biological Chemistry 270 20424-20431. (https://doi.org/10.1074/jbc.270.35.20424)

Mohanraj L, Kim HS, Li W, Cai Q, Kim KE, Shin HJ, Lee YJ, Lee WJ, Kim JH \& Oh Y 2013 IGFBP3 inhibits cytokine-induced insulin resistance and early manifestations of atherosclerosis. PLOS ONE $\mathbf{8}$ e55084. (https://doi.org/10.1371/journal.pone.0055084)

Mukherjee A \& Rotwein P 2008 Insulin-like growth factor-binding protein-5 inhibits osteoblast differentiation and skeletal growth by blocking insulin-like growth factor actions. Molecular Endocrinology 22 1238-1250. (https://doi.org/10.1210/me.2008-0001)

Mukherjee A, Wilson EM \& Rotwein P 2008 Insulin-like growth factor (IGF) binding protein-5 blocks skeletal muscle differentiation by inhibiting IGF actions. Molecular Endocrinology 22 206-215. (https:// doi.org/10.1210/me.2007-0336)

Murphy LJ 2000 Overexpression of insulin-like growth factor binding protein-1 in transgenic mice. Pediatric Nephrology 14 567-571. (https://doi.org/10.1007/s004670000347)

Nam SY, Lee EJ, Kim KR, Cha BS, Song YD, Lim SK, Lee HC \& Huh KB 1997 Effect of obesity on total and free insulin-like growth factor (IGF)-1, and their relationship to IGF-binding protein (BP)-1, IGFBP2, IGFBP3, insulin, and growth hormone. International Journal of Obesity and Related Metabolic Disorders 21 355-359. (https://doi. org/10.1038/sj.ijo.0800412)

Narayanan RP, Fu B, Oliver RL, Siddals KW, Donn R, Hudson JE, White A, Laing I, Ollier WE, Heald AH \& Gibson JM 2014 Insulinlike growth factor-II and insulin-like growth factor binding protein-2 prospectively predict longitudinal elevation of HDL-cholesterol in type 2 diabetes. Annals of Clinical Biochemistry 51 468-475. (https:// doi.org/10.1177/0004563213499145)

Narusawa K, Nakamura T, Suzuki K, Matsuoka Y, Lee LJ, Tanaka H \& Seino Y 1995 The effects of recombinant human insulin-like growth factor (rhIGF)-1 and rhIGF-1/IGF binding protein-3 administration on rat osteopenia induced by ovariectomy with concomitant bilateral sciatic neurectomy. Journal of Bone and Mineral Research 10 1853-1864. (https://doi.org/10.1002/jbmr.5650101204)

Nedić O, Masnikosa R \& Lagundžin D 2011 Association between the pattern of IGFBP1 alteration and the glucose/insulin metabolic control. Experimental and Clinical Endocrinology and Diabetes 119 306-313.

Nguyen KH, Mishra S \& Nyomba BL $2015 a$ In vitro differentiation of mouse brown preadipocytes is enhanced by IGFBP3 expression and reduced by IGFBP3 silencing. Obesity 23 2083-2092. (https://doi. org/10.1002/oby.21204)

Nguyen KH, Yao XH, Erickson AG, Mishra S \& Nyomba BL 2015b Glucose intolerance in aging male IGFBP3 transgenic mice: differential effects of human IGFBP3 and its mutant IGFBP3 devoid of IGF binding ability. Endocrinology 156 462-474. (https://doi. org/10.1210/en.2014-1271)

Nichols TC, Busby WH Jr, Merricks E, Sipos J, Rowland M, Sitko K \& Clemmons DR 2007 Protease-resistant insulin-like growth factor (IGF)-binding protein-4 inhibits IGF-I actions and neointimal expansion in a porcine model of neointimal hyperplasia. Endocrinology 148 5002-5010. (https://doi.org/10.1210/en.2007-0571)

Ning Y, Schuller AG, Bradshaw S, Rotwein P, Ludwig T, Frystyk J \& Pintar JE 2006 Diminished growth and enhanced glucose metabolism in triple knockout mice containing mutations of insulin -like growth factor binding protein-3, -4, and -5. Molecular Endocrinology 20 2173-2186. (https://doi.org/10.1210/me.2005-0196)

Ning Y, Hoang B, Schuller AG, Cominski TP, Hsu MS, Wood TL \& Pintar JE 2007 Delayed mammary gland involution in mice with mutation of the insulin-like growth factor binding protein 5 gene. Endocrinology 148 2138-2147. (https://doi.org/10.1210/en.20060041)

Oikonomopoulos A, Sereti KI, Conyers F, Bauer M, Liao A, Guan J, Crapps D, Han JK, Dong H, Bayomy AF, et al. 2011 Wnt signaling exerts an antiproliferative effect on adult cardiac progenitor cells through IGFBP3. Circulation Research 109 1363-1374. (https://doi. org/10.1161/CIRCRESAHA.111.250282)

Okazaki R, Riggs BL \& Conover CA 1994 Glucocorticoid regulation of insulin-like growth factor-binding protein expression in normal human osteoblast-like cells. Endocrinology 134 126-132. (https://doi. org/10.1210/endo.134.1.7506203)

Oliver WT, Rosenberger J, Lopez R, Gomez A, Cummings KK \& Fiorotto ML 2005 The local expression and abundance of insulin-like growth factor (IGF) binding proteins in skeletal muscle are regulated by age and gender but not local IGF-I in vivo. Endocrinology 146 5455-5462. (https://doi.org/10.1210/en.2005-0714)

Olszanecka A, Dragan A, Kawecka-Jaszcz K, Fedak D \& Czarnecka D 2017 Relationships of insulin-like growth factor-1, its binding proteins, and cardiometabolic risk in hypertensive perimenopausal women. Metabolism 69 96-106. (https://doi.org/10.1016/j. metabol.2017.01.005)

Ooi GT, Tseng LY \& Rechler MM 1993 Transcriptional regulation of the rat IGFBP1 and IGFBP2 genes. Growth Regulation 3 14-17

Palau N, Rebuffat SA, Altirriba J, Piquer S, Hanzu FA, Gomis R \& Barbera A 2012 Role of IGFBP3 in the regulation of $\beta$-cell mass during obesity: adipose tissue/ $\beta$-cell cross talk. Endocrinology 153 177-187. (https://doi.org/10.1210/en.2011-0181)

Palermo C, Manduca P, Gazzerro E, Foppiani L, Segat D \& Barreca A 2004 Potentiating role of IGFBP2 on IGF-II-stimulated alkaline phosphatase activity in differentiating osteoblasts. American Journal of Physiology-Endocrinology and Metabolism 286 E648-E657. (https:// doi.org/10.1152/ajpendo.00049.2003)

Pampusch MS, Kamanga-Sollo E, White ME, Hathaway MR \& Dayton WR 2003 Effect of recombinant porcine IGF-binding protein-3 on proliferation of embryonic porcine myogenic cell cultures in the presence and absence of IGF-I. Journal of Endocrinology 176 227-235. (https://doi.org/10.1677/joe.0.1760227)

Pampusch MS, Xi G, Kamanga-Sollo E, Loseth KJ, Hathaway MR, Dayton WR \& White ME 2005 Production of recombinant porcine IGF-binding protein-5 and its effect on proliferation of porcine embryonic myoblast cultures in the presence and absence of IGF-I and Long-R3-IGF-I. Journal of Endocrinology 185 197-206. (https:// doi.org/10.1677/joe.1.06037)

Petäjä EM, Zhou Y, Havana M, Hakkarainen A, Lundbom N, Ihalainen J \& Yki-Järvinen H 2016 Phosphorylated IGFBP1 as a non-invasive predictor of liver fat in NAFLD. Scientific Reports 624740.

Petersson U, Ostgren CJ, Brudin L, Brismar K \& Nilsson PM 2009 Low levels of insulin-like growth-factor-binding protein-1 (IGFBP1) are prospectively associated with the incidence of type 2 diabetes and impaired glucose tolerance (IGT): the Söderåkra Cardiovascular Risk 
Factor Study. Diabetes and Metabolism 35 198-205. (https://doi. org/10.1016/j.diabet.2008.11.003)

Player DJ, Martin NR, Passey SL, Sharples AP, Mudera V \& Lewis MP 2014 Acute mechanical overload increases IGF-I and MMP-9 mRNA in 3D tissue-engineered skeletal muscle. Biotechnology Letters 36 1113-1124. (https://doi.org/10.1007/s10529-014-1464-y)

Pye SR, Almusalam B, Boonen S, Vanderschueren D, Borghs H, Gielen E, Adams JE, Ward KA, Bartfai G, Casanueva FF, et al. 2011 Influence of insulin-like growth factor binding protein (IGFBP)-1 and IGFBP3 on bone health: results from the European Male Ageing Study. Calcified Tissue International 88 503-510. (https://doi.org/10.1007/s00223-0119484-2)

Qin X, Byun D, Strong DD, Baylink DJ \& Mohan S 1999 Studies on the role of human insulin-like growth factor-II (IGF-II)-dependent IGF binding protein (hIGFBP)-4 protease in human osteoblasts using protease-resistant IGFBP4 analogs. Journal of Bone and Mineral Research 14 2079-2088. (https://doi.org/10.1359/ ibmr.1999.14.12.2079)

Radetti G, Bozzola M, Pasquino B, Paganini C, Aglialoro A, Livieri C \& Barreca A 1998 Growth hormone bioactivity, insulin-like growth factors (IGFs), and IGF binding proteins in obese children. Metabolism 47 1490-1493. (https://doi.org/10.1016/S00260495(98)90075-0)

Rahman S, Lu Y, Czernik PJ, Rosen CJ, Enerback S \& Lecka-Czernik B 2013 Inducible brown adipose tissue, or beige fat, is anabolic for the skeleton. Endocrinology 154 2687-2701. (https://doi.org/10.1210/ en.2012-2162)

Rajkumar K, Modric T \& Murphy LJ 1999 Impaired adipogenesis in insulin-like growth factor binding protein-1 transgenic mice. Journal of Endocrinology 162 457-465. (https://doi.org/10.1677/ joe.0.1620457)

Rajpathak SN, He M, Sun Q, Kaplan RC, Muzumdar R, Rohan TE, Gunter MJ, Pollak M, Kim M, Pessin JE, et al. 2012 Insulin-like growth factor axis and risk of type 2 diabetes in women. Diabetes $\mathbf{6 1}$ 2248-2254. (https://doi.org/10.2337/db11-1488)

Rajwani A, Ezzat V, Smith J, Yuldasheva NY, Duncan ER, Gage M, Cubbon RM, Kahn MB, Imrie H, Abbas A, et al. 2012 Increasing circulating IGFBP1 levels improves insulin sensitivity, promotes nitric oxide production, lowers blood pressure, and protects against atherosclerosis. Diabetes 61 915-924. (https://doi.org/10.2337/db110963)

Ramirez VI, Miller E, Meireles CL, Gelfond J, Krummel DA \& Powell TL 2014 Adiponectin and IGFBP1 in the development of gestational diabetes in obese mothers. BMJ Open Diabetes Research and Care $\mathbf{2}$ e000010. (https://doi.org/10.1136/bmjdrc-2013-000010)

Ramshanker N, Aagaard M, Hjortebjerg R, Voss TS, Møller N, Jørgensen JOL, Jessen N, Bjerring P, Magnusson NE, Bjerre M, et al. 2017 Effects of prednisolone on serum and tissue fluid IGF-I receptor activation and post-receptor signaling in humans. Journal of Clinical Endocrinology and Metabolism 102 4031-4040. (https://doi. org/10.1210/jc.2017-00696)

Raslan HM, Elhosary Y, Ezzat WM, Rasheed EA \& Rasheed MA 2010 The potential role of insulin-like growth factor 1, insulin-like growth factor binding protein 3 and bone mineral density in patients with chronic hepatitis C virus in Cairo, Egypt. Transactions of the Royal Society of Tropical Medicine and Hygiene 104 429-432. (https://doi. org/10.1016/j.trstmh.2010.01.012)

Rehage M, Mohan S, Wergedal JE, Bonafede B, Tran K, Hou D, Phang D, Kumar A \& Qin X 2007 Transgenic overexpression of pregnancyassociated plasma protein-A increases the somatic growth and skeletal muscle mass in mice. Endocrinology 148 6176-6185. (https:// doi.org/10.1210/en.2007-0274)

Rehfeldt C, Renne U, Sawitzky M, Binder G \& Hoeflich A 2010 Increased fat mass, decreased myofiber size, and a shift to glycolytic muscle metabolism in adolescent male transgenic mice overexpressing
IGFBP2. American Journal of Physiology-Endocrinology and Metabolism 299 E287-E298. (https://doi.org/10.1152/ajpendo.00492.2009)

Reinehr T, Kleber M, Toschke AM, Woelfle J \& Roth CL 2011 Longitudinal association between IGFBP1 levels and parameters of the metabolic syndrome in obese children before and after weight loss. International Journal of Pediatric Obesity 6 236-243. (https://doi. org/10.3109/17477166.2010.544739)

Ren H, Yin P \& Duan C 2008 IGFBP5 regulates muscle cell differentiation by binding to IGF-II and switching on the IGF-II auto-regulation loop. Journal of Cell Biology 182 979-991. (https:// doi.org/10.1083/jcb.200712110)

Reyer A, Schindler N, Ohde D, Walz C, Kunze M, Tuchscherer A, Wirthgen E, Brenmoehl J \& Hoeflich A 2015 The RGD sequence present in IGFBP2 is required for reduced glucose clearance after oral glucose administration in female transgenic mice. American Journal of Physiology-Endocrinology and Metabolism 309 E409-E417. (https://doi. org/10.1152/ajpendo.00168.2015)

Ricort JM \& Binoux MJ 2002 Insulin-like growth factor-binding protein-3 activates a phosphotyrosine phosphatase. Effects on the insulin-like growth factor signaling pathway. Journal of Biological Chemistry 277 19448-19454. (https://doi.org/10.1074/jbc. M200439200)

Rosendal L, Langberg H, Flyvbjerg A, Frystyk J, Ørskov H \& Kjaer M 2002 Physical capacity influences the response of insulin-like growth factor and its binding proteins to training. Journal of Applied Physiology 93 1669-1675. (https://doi.org/10.1152/ japplphysiol.00145.2002)

Rousse S, Montarras D, Pinset C \& Dubois C 1998 Up-regulation of insulin-like growth factor binding protein-5 is independent of muscle cell differentiation, sensitive to rapamycin, but insensitive to wortmannin and LY294002. Endocrinology 139 1487-1493. (https:// doi.org/10.1210/endo.139.4.5916)

Rubinow KB \& Bornfeldt KE 2012 Microvascular management of systemic insulin sensitivity. Circulation Research 111 951-953. (https://doi.org/10.1161/CIRCRESAHA.112.278382)

Russo VC, Bach LA, Fosang AJ, Baker NL \& Werther GA 1997 Insulinlike growth factor binding protein-2 binds to cell surface proteoglycans in the rat brain olfactory bulb. Endocrinology 138 4858-4856. (https://doi.org/10.1210/endo.138.11.5472)

Russo VC, Azar WJ, Yau SW, Sabin MA \& Werther GA 2015 IGFBP2: the dark horse in metabolism and cancer. Cytokine and Growth Factor Reviews 26 329-346. (https://doi.org/10.1016/j.cytogfr.2014.12.001)

Safian D, Fuentes EN, Valdés JA \& Molina A 2012 Dynamic transcriptional regulation of autocrine/paracrine igfbp1, 2, 3, 4, 5, and 6 in the skeletal muscle of the fine flounder during different nutritional statuses. Journal of Endocrinology 214 95-108. (https://doi. org/10.1530/JOE-12-0057)

Saini A, Sharples AP, Al-Shanti N \& Stewart CE 2017 Omega-3 fatty acid EPA improves regenerative capacity of mouse skeletal muscle cells exposed to saturated fat and inflammation. Biogerontology 18 109-129. (https://doi.org/10.1007/s10522-016-9667-3)

Sakai K, D'Ercole AJ, Murphy LJ \& Clemmons DR 2001 Physiological differences in insulin-like growth factor binding protein-1 (IGFBP1) phosphorylation in IGFBP1 transgenic mice. Diabetes 50 32-38. (https://doi.org/10.2337/diabetes.50.1.32)

Salih DA, Mohan S, Kasukawa Y, Tripathi G, Lovett FA, Anderson NF, Carter EJ, Wergedal JE, Baylink DJ \& Pell JM 2005 Insulin-like growth factor-binding protein-5 induces a gender-related decrease in bone mineral density in transgenic mice. Endocrinology 146 931-940. (https://doi.org/10.1210/en.2004-0816)

Saukkonen T, Shojaee-Moradie F, Williams RM, Amin R, Yuen KC, Watts A, Acerini CL, Umpleby AM \& Dunger DB 2006 Effects of recombinant human IGF-I/IGF-binding protein-3 complex on glucose and glycerol metabolism in type 1 diabetes. Diabetes $\mathbf{5 5}$ 2365-2370. (https://doi.org/10.2337/db05-1646) 
Savastano S, Di Somma C, Pizza G, De Rosa A, Nedi V, Rossi A, Orio F, Lombardi G, Colao A \& Tarantino G 2011 Liver-spleen axis, insulinlike growth factor-(IGF)-I axis and fat mass in overweight/obese females. Journal of Translational Medicine 16 136. (https://doi. org/10.1186/1479-5876-9-136)

Scharla SH, Strong DD, Rosen C, Mohan S, Holick M, Baylink DJ \& Linkhart TA 1993 1,25-Dihydroxyvitamin D3 increases secretion of insulin-like growth factor binding protein-4 (IGFBP4) by human osteoblast-like cells in vitro and elevates IGFBP4 serum levels in vivo. Journal of Clinical Endocrinology and Metabolism 77 1190-1197.

Schedlich LJ, Muthukaruppan A, O'Han MK \& Baxter RC 2007 Insulinlike growth factor binding protein-5 interacts with the vitamin D receptor and modulates the vitamin $\mathrm{D}$ response in osteoblasts. Molecular Endocrinology 21 2378-2390. (https://doi.org/10.1210/ me.2006-0558)

Schmid C, Schläpfer I, Keller A, Waldvogel M, Froesch ER \& Zapf J 1995 Effects of insulin-like growth factor (IGF) binding proteins (BPs) -3 and -6 on DNA synthesis of rat osteoblasts: further evidence for a role of auto-/paracrine IGF I but not IGF II in stimulating osteoblast growth. Biochemical and Biophysical Research Communications 212 242-248. (https://doi.org/10.1006/bbrc.1995.1962)

Seferovic MD, Ali R, Kamei H, Liu S, Khosravi JM, Nazarian S, Han VK, Duan C \& Gupta MB 2009 Hypoxia and leucine deprivation induce human insulin-like growth factor binding protein-1 hyperphosphorylation and increase its biological activity. Endocrinology 150 220-231. (https://doi.org/10.1210/en.2008-0657)

Sharma A, Purohit S, Sharma S, Bai S, Zhi W, Ponny SR, Hopkins D, Steed L, Bode B, Anderson SW, et al. 2016 IGF-binding proteins in type- 1 diabetes are more severely altered in the presence of complications. Frontiers in Endocrinology 7 2-21.

Sharples AP, Al-Shanti N, Hughes DC, Lewis MP \& Stewart CE 2013 The role of insulin-like-growth factor binding protein 2 (IGFBP2) and phosphatase and tensin homologue (PTEN) in the regulation of myoblast differentiation and hypertrophy. Growth Hormone and IGF Research 23 53-61. (https://doi.org/10.1016/j.ghir.2013.03.004)

Shen X, Xi G, Maile LA, Wai C, Rosen CJ \& Clemmons DR 2012 Insulinlike growth factor (IGF) binding protein 2 functions coordinately with receptor protein tyrosine phosphatase $\beta$ and the IGF-I receptor to regulate IGF-I-stimulated signaling. Molecular and Cellular Biology 32 4116-4130. (https://doi.org/10.1128/MCB.01011-12)

Shen X, Xi G, Wai C \& Clemmons DR 2015 The coordinate cellular response to insulin-like growth factor-I (IGF-I) and insulin-like growth factor-binding protein-2 (IGFBP2) is regulated through vimentin binding to receptor tyrosine phosphatase $\beta$ (RPTP $\beta$ ). Journal of Biological Chemistry 290 11578-11590. (https://doi.org/10.1074/ jbc.M114.620237)

Siddals KW, Westwood M, Gibson JM \& White A 2002 IGF-binding protein-1 inhibits IGF effects on adipocyte function: implications for insulin-like actions at the adipocyte. Journal of Endocrinology $\mathbf{1 7 4}$ 289-297. (https://doi.org/10.1677/joe.0.1740289)

Silha JV, Gui Y \& Murphy LJ 2002 Impaired glucose homeostasis in insulin-like growth factor-binding protein-3-transgenic mice. American Journal of Physiology-Endocrinology and Metabolism 283 E937-E945. (https://doi.org/10.1152/ajpendo.00014.2002)

Silha JV, Mishra S, Rosen CJ, Beamer WG, Turner RT, Powell DR \& Murphy LJ 2003 Perturbations in bone formation and resorption in insulin-like growth factor binding protein-3 transgenic mice. Journal of Bone and Mineral Research 18 1834-1841. (https://doi.org/10.1359/ jbmr.2003.18.10.1834)

Snyder DK \& Clemmons DR 1990 Insulin-dependent regulation of insulin-like growth factor-binding protein-1. Journal of Clinical Endocrinology and Metabolism 71 1632-1636. (https://doi. org/10.1210/jcem-71-6-1632)

Sorensen JS, Birkebaek NH, Bjerre M, Pociot F, Kristensen K, Hoejberg AS, Frystyk J \& Danish Society for Diabetes in Childhood and Adolescence 2015 Residual $\beta$-cell function and the insulin-like growth factor system in Danish children and adolescents with type 1 diabetes. Journal of Clinical Endocrinology and Metabolism 100 1053-1061. (https://doi.org/10.1210/jc.2014-3521)

Spangenburg EE, Abraha T, Childs TE, Pattison JS \& Booth FW 2003 Skeletal muscle IGF-binding protein-3 and -5 expressions are age, muscle, and load dependent. American Journal of PhysiologyEndocrinology and Metabolism 284 E340-E350. (https://doi. org/10.1152/ajpendo.00253.2002)

Spilcke-Liss E, Friedrich N, Dörr M, Schminke U, Völzke H, Brabant G, Nauck M \& Wallaschofski H 2011 Serum insulin-like growth factor I and its binding protein 3 in their relation to intima-media thickness: results of the study of health in Pomerania (SHIP). Clinical Endocrinology 75 70-75. (https://doi. org/10.1111/j.1365-2265.2011.04010.x)

Stevens-Lapsley JE, Ye F, Liu M, Borst SE, Conover C, Yarasheski KE, Walter GA, Sweeney HL \& Vandenborne K 2010 Impact of viralmediated IGF-I gene transfer on skeletal muscle following cast immobilization. American Journal of Physiology-Endocrinology and Metabolism 299 E730-E740. (https://doi.org/10.1152/ ajpendo.00230.2010)

Stilling F, Wallenius S Michaëlsson K, Dalgård C, Brismar K \& Wolk A 2017 High insulin-like growth factor-binding protein-1 (IGFBP1) is associated with low relative muscle mass in older women. Metabolism 73 36-42. (https://doi.org/10.1016/j. metabol.2017.04.013)

Street ME, Smerieri A, Montanini L, Predieri B, Iughetti L, Valenzise M, De Luca F, Vigone M, Weber G, Maghnie M, et al. 2013 Interactions among pro-inflammatory cytokines, IGF system and thyroid function in pre-pubertal obese subjects. Journal of Biological Regulators and Homeostatic Agents 27 259-266.

Strohbach C, Kleinman S, Linkhart T, Amaar Y, Chen ST, Mohan S \& Strong D 2008 Potential involvement of the interaction between insulin-like growth factor binding protein (IGFBP)-6 and LIM mineralization protein (LMP)-1 in regulating osteoblast differentiation. Journal of Cellular Biochemistry 104 1890-1905. (https://doi.org/10.1002/jcb.21761)

Suwanickul A, Morris SL \& Powell DR 1993 Identification of an insulinresponsive element in the promoter of the human gene for insulinlike growth factor binding protein-1. Journal of Biological Chemistry 268 17063-17068.

Svanberg E, Ohlsson C, Kimball SR \& Lundholm K 2000 hIGF-I/IGFBP3 complex, but not free rhIGF-I, supports muscle protein biosynthesis in rats during semistarvation. European Journal of Clinical Investigation 30 438-446. (https://doi.org/10.1046/j.1365-2362.2000.00652.x)

Swiderski K, Martins KJ, Chee A, Trieu J, Naim T, Gehrig SM, Baum DM, Brenmoehl J, Chau L, Koopman R, et al. 2016 Skeletal musclespecific overexpression of IGFBP2 promotes a slower muscle phenotype in healthy but not dystrophic mdx mice and does not affect the dystrophic pathology. Growth Hormone and IGF Research 30-31 1-10. (https://doi.org/10.1016/j.ghir.2016.07.002)

Thorén M, Hilding A, Brismar T, Magnusson P, Degerblad M, Larsson L, Sääf M, Baylink DJ \& Mohan S 1998 Serum levels of insulin-like growth factor binding proteins (IGFBP)-4 and -5 correlate with bone mineral density in growth hormone $(\mathrm{GH})$-deficient adults and increase with GH replacement therapy. Journal of Bone and Mineral Research 13 891-899.

Touskova V, Trachta P, Kavalkova P, Drapalova J, Haluzikova D, Mraz M, Lacinova Z, Marek J \& Haluzik M 2012 Serum concentrations and tissue expression of components of insulin-like growth factor-axis in females with type 2 diabetes mellitus and obesity: the influence of very-low-calorie diet. Molecular and Cellular Endocrinology 361 172-178. (https://doi.org/10.1016/j.mce.2012.04.005)

Ukkola O, Sun G \& Bouchard C 2001 Insulin-like growth factor 2 (IGF2) and IGF-binding protein 1 (IGFBP1) gene variants are associated with overfeeding-induced metabolic changes. Diabetologia $\mathbf{4 4}$ 2231-2236. (https://doi.org/10.1007/s001250100034) 
Urbonaviciene G, Frystyk J, Urbonavicius S \& Lindholt JS 2014 IGF-I and IGFBP2 in peripheral artery disease: results of a prospective study Scandinavian Cardiovascular Journal 48 99-105. (https://doi.org/ 10.3109/14017431.2014.891760)

van den Beld AW, Blum WF, Brugts MP, Janssen JA, Grobbee DE \& Lamberts SW 2012 High IGFBP2 levels are not only associated with a better metabolic risk profile but also with increased mortality in elderly men. European Journal of Endocrinology 167 111-117. (https:// doi.org/10.1530/EJE-12-0160)

van der Kaay D, Deal C, de Kort S, Willemsen R, Leunissen R, Ester W, Paquette J, van Doorn J \& Hokken-Koelega A 2009 Insulin-like growth factor-binding protein-1: serum levels, promoter polymorphism, and associations with components of the metabolic syndrome in short subjects born small for gestational age Journal of Clinical Endocrinology and Metabolism 94 1386-1392. (https://doi. org/10.1210/jc.2008-1430)

van Dijk PR, Logtenberg SJ, Chisalita SI, Hedman CA, Groenier KH, Gans RO, Kleefstra N, Arnqvist HJ \& Bilo HJ 2016 Different effects of intraperitoneal and subcutaneous insulin administration on the GH-IGF-1 axis in type 1 diabetes. Journal of Clinical Endocrinology and Metabolism 101 2493-2501. (https://doi.org/10.1210/jc.20161473)

Wang J, Razuvaev A, Folkersen L, Hedin E, Roy J, Brismar K \& Hedin U 2012 The expression of IGFs and IGF binding proteins in human carotid atherosclerosis, and the possible role of IGF binding protein-1 in the regulation of smooth muscle cell proliferation. Atherosclerosis 220 102-109. (https://doi.org/10.1016/j. atherosclerosis.2011.10.032)

Wang X, Wei W, Krzeszinski JY, Wang Y \& Wan Y 2015 A liver-bone endocrine relay by IGFBP1 promotes osteoclastogenesis and mediates FGF21-induced bone resorption. Cell Metabolism 22 811-824. (https://doi.org/10.1016/j.cmet.2015.09.010)

Watanabe T, Itokawa M, Nakagawa Y, Iguchi T \& Katagiri T 2003 Increased levels of insulin-like growth factor binding protein-3 in hypertensive patients with carotid atherosclerosis. American Journal of Hypertension 16 754-760. (https://doi.org/10.1016/S0895-7061(03)00985-3)

Weaver JU, Holly JM, Kopelman PG, Noonan K, Giadom CG, White N, Virdee S \& Wass JA 1990 Decreased sex hormone binding globulin (SHBG) and insulin-like growth factor binding protein (IGFBP1) in extreme obesity. Clinical Endocrinology 33 415-422. (https://doi. $\operatorname{org} / 10.1111 /$ j.1365-2265.1990.tb00507.x)

Wheatcroft SB \& Kearney MT 2009 IGF-dependent and IGF-independent actions of IGF-binding protein-1 and -2: implications for metabolic homeostasis. Trends in Endocrinology and Metabolism 20 153-162. (https://doi.org/10.1016/j.tem.2009.01.002)

Wheatcroft SB, Kearney MT, Shah AM, Ezzat VA, Miell JR, Modo M, Williams SC, Cawthorn WP, Medina-Gomez G, Vidal-Puig A, et al. 2007 IGF-binding protein-2 protects against the development of obesity and insulin resistance. Diabetes 56 285-294. (https://doi. org/10.2337/db06-0436)

Wiedmer P, Schwarz F, Große B, Schindler N, Tuchscherer A, Russo VC, Tschöp MH \& Hoeflich A 2015 Gender-specific effects on food intake but no inhibition of age-related fat accretion in transgenic mice overexpressing human IGFBP2 lacking the Cardin-Weintraub sequence motif. Journal of Cell Communication and Signaling 9 143-150. (https://doi.org/10.1007/s12079-015-0264-z)

Williams NG, Interlichia JP, Jackson MF, Hwang D, Cohen P \& Rodgers BD 2011 Endocrine actions of myostatin: systemic regulation of the IGF and IGF binding protein axis. Endocrinology 152 172-180. (https://doi.org/10.1210/en.2010-0488)

Xi G, Solum MA, Wai C, Maile LA, Rosen CJ \& Clemmons DR 2013 The heparin-binding domains of IGFBP2 mediate its inhibitory effect on preadipocyte differentiation and fat development in male mice. Endocrinology 154 4146-4157. (https://doi.org/10.1210/en.2013-1236)

Xi G, Rosen CJ \& Clemmons DR 2016 IGF-I and IGFBP2 stimulate AMPK activation and autophagy, which are required for osteoblast differentiation. Endocrinology 157 268-281. (https://doi.org/10.1210/ en.2015-1690)

Xian L, Wu X, Pang L, Lou M, Rosen CJ, Qiu T, Crane J, Frassica F, Zhang L, Rodriguez JP, et al. 2012 Matrix IGF-1 maintains bone mass by activation of mTOR in mesenchymal stem cells. Nature Medicine 18 1095-1101. (https://doi.org/10.1038/nm.2793)

Yakar S, Rosen CJ, Bouxsein ML, Sun H, Mejia W, Kawashima Y, Wu Y, Emerton K, Williams V, Jepsen K, et al. 2009 Serum complexes of insulin-like growth factor-1 modulate skeletal integrity and carbohydrate metabolism. FASEB Journal 23 709-719. (https://doi. org/10.1096/fj.08-118976)

Yamada PM, Mehta HH, Hwang D, Roos KP, Hevener AL \& Lee KW 2010 Evidence of a role for insulin-like growth factor binding protein (IGFBP)-3 in metabolic regulation. Endocrinology 151 5741-5750. (https://doi.org/10.1210/en.2010-0672)

Yamaguchi T, Kanatani M, Yamauchi M, Kaji H, Sugishita T, Baylink DJ, Mohan S, Chihara K \& Sugimoto T 2006 Serum levels of insulin-like growth factor (IGF); IGF-binding proteins-3, -4, and -5; and their relationships to bone mineral density and the risk of vertebral fractures in postmenopausal women. Calcified Tissue International $\mathbf{7 8}$ 18-24. (https://doi.org/10.1007/s00223-005-0163-z)

Yang CW, Li TC, Li CI, Liu CS, Lin CH, Lin WY \& Lin CC 2015 Insulinlike growth factor-1 and its binding protein-3 polymorphisms predict circulating IGF-1 level and appendicular skeletal muscle mass in Chinese elderly. Journal of the American Medical Directors Association 16 365-370. (https://doi.org/10.1016/j. jamda.2014.11.015)

Yeap BB, Chubb SA, Ho KK, Setoh JW, McCaul KA, Norman PE, Jamrozik K \& Flicker L 2010 IGF1 and its binding proteins 3 and 1 are differentially associated with metabolic syndrome in older men. European Journal of Endocrinology 162 249-257. (https://doi. org/10.1530/EJE-09-0852)

Yeap BB, Chubb SA, McCaul KA, Ho KK, Hankey GJ, Norman PE \& Flicker L 2011 Associations of IGF1 and IGFBPs 1 and 3 with allcause and cardiovascular mortality in older men: the Health In Men Study. European Journal of Endocrinology 164 715-723. (https://doi. org/10.1530/EJE-11-0059)

Yeh LC, Adamo ML, Olson MS \& Lee JC 1997 Osteogenic protein-1 and insulin-like growth factor I synergistically stimulate rat osteoblastic cell differentiation and proliferation. Endocrinology 138 4181-4190. (https://doi.org/10.1210/endo.138.10.5465)

Yin P, Xu Q \& Duan C 2004 Paradoxical actions of endogenous and exogenous insulin-like growth factor-binding protein-5 revealed by RNA interference analysis. Journal of Biological Chemistry 279 32660-32666. (https://doi.org/10.1074/jbc.M401378200)

Zachrisson I, Brismar K, Carlsson-Skwirut C, Dahlquist G, Wallensteen M \& Bang P 2000 Increased $24 \mathrm{~h}$ mean insulin-like growth factor binding protein-3 proteolytic activity in pubertal type 1 diabetic boys. Growth Hormone and IGF Research 10 324-331. (https://doi. org/10.1054/ghir.2000.0170)

Zdanowicz MM \& Teichberg S 2003 Effects of insulin-like growth factor-1/binding protein-3 complex on muscle atrophy in rats Experimental Biology and Medicine 228 891-897. (https://doi. org/10.1177/153537020322800804)

Żebrowska A, Waśkiewicz Z, Zając A, Gąsior Z, Galbo H \& Langfort J 2013 IGF-1 response to arm e7ercise with eccentric and concentric muscle contractions in resistance-trained athletes with left ventricular hypertrophy. International Journal of Sports Medicine 34 116-122.

Zhang M, Faugere MC, Malluche H, Rosen CJ, Chernausek SD \& Clemens TL 2003 Paracrine overexpression of IGFBP4 in osteoblasts of transgenic mice decreases bone turnover and causes global growth retardation. Journal of Bone and Mineral Research 18 836-843. (https:// doi.org/10.1359/jbmr.2003.18.5.836)

Zhang Q, Jiang Y \& Steinle JJ 2015 IGFBP3 reduces eNOS and PKCzeta phosphorylation, leading to lowered VEGF levels. Molecular Vision 21 604-611. 
Zhao D, Shen L, Wei Y, Xie J, Chen S, Liang Y, Chen Y \& Wu H 2017 Identification of candidate biomarkers for the prediction of gestational diabetes mellitus in the early stages of pregnancy using iTRAQ quantitative proteomics. PROTEOMICS - Clinical Applications 117-8. (https://doi.org/10.1002/prca.201600152)

Zheng W, Lai Y, Jin P, Gu W, Zhou Q \& Wu X 2017 Association of circulating IGFBP1 level with the severity of coronary artery lesions in patients with unstable angina. Disease Markers 20171917291.
Zhong Y, Lu L, Zhou J, Li Y, Liu Y, Clemmons DR \& Duan C 2011 IGF binding protein 3 exerts its ligand-independent action by antagonizing BMP in zebrafish embryos. Journal of Cell Science 124 1925-1935. (https://doi.org/10.1242/jcs.082644)

Zhu Y, Mendola P, Albert PS, Bao W, Hinkle SN, Tsai MY \& Zhang C 2016 Insulin-like growth factor axis and gestational diabetes mellitus: a longitudinal study in a multiracial cohort. Diabetes $\mathbf{6 5}$ 3495-3504. (https://doi.org/10.2337/db16-0514)

Received in final form 14 March 2018

Accepted 21 March 2018

Accepted Preprint published online 21 March 2018 